\title{
How Preussag became TUI: Kissing too many toads can make you a toad*
}

\author{
Ingolf Dittmann $^{\mathrm{a}} \quad$ Ernst Maug ${ }^{\mathrm{b}} \quad$ Christoph Schneider $^{\mathrm{c}}$
}

\author{
First draft: September 2, 2004 \\ This draft: May 9, 2006
}

Abridged version forthcoming in Financial Management. ${ }^{d}$

\begin{abstract}
In the period 1997-2004, Preussag, a diversified German conglomerate of old economy businesses, changed itself into TUI, a company focused almost entirely on tourism and logistics. This paper analyzes how this strategy was executed and how it contributed to Preussag's underperformance of the stock market. We collect 417 announcements of acquisitions, financial disclosures and other news and disentangle the impact of different parts of the company's strategy. We find that only the divestitures created value, that the strategy to invest in tourism destroyed value, and that the acquisition premiums Preussag paid were mostly unjustified. Bad luck like the events of September 11, 2001 cannot account for the poor performance of the stock. Poor management resulted from poor governance, combining a state-owned bank as the largest shareholder, board interlocks, and insufficient managerial incentives. The case shows how divestiture programs increase the liquid resources available to management beyond free operating cash flows and casts doubt on the positive governance role of institutional blockholders.
\end{abstract}

\section{JEL classifications: G32, G34}

Keywords: $\quad$ Corporate Governance, Large shareholders, Germany, Diversification, Mergers and Acquisitions

* This is an academic study and was conducted only to make a contribution to the scientific debate on corporate governance. The study was not conducted on behalf of a third party and none of the authors received any funds from any party mentioned in this paper. We are grateful to Michel Habib, Martin Wallmeier, and to the Jury members of the JFE ECGI Clinical Paper Competition, especially Steve Kaplan and Claudio Loderer, for their comments. Christoph Schneider acknowledges the support of a DekaBank scholarship.

a Erasmus University Rotterdam, P.O. Box 1738, 3000 DR, Rotterdam, The Netherlands. Email: dittmann@few.eur.nl. Tel: +31 104081283.

b Universität Mannheim, D-61381 Mannheim, Germany. Email: maug@bwl.uni-mannheim.de, Tel: +49621181 1952 .

c Universität Mannheim, D-61381 Mannheim, Germany. Email: schneider@bwl.uni-mannheim.de, Tel: +49 6211811949 .

d An abridged version of this paper with the title "How Preussag became TUI: A clinical study of blockholders and restructuring in Europe” is forthcoming in Financial Management. 


\title{
How Preussag became TUI: Kissing too many toads can make you a toad
}

\begin{abstract}
In the period 1997-2004, Preussag, a diversified German conglomerate of old economy businesses, changed itself into TUI, a company focused almost entirely on tourism and logistics. This paper analyzes how this strategy was executed and how it contributed to Preussag's underperformance of the stock market. We collect 417 announcements of acquisitions, financial disclosures and other news and disentangle the impact of different parts of the company's strategy. We find that only the divestitures created value, that the strategy to invest in tourism destroyed value, and that the acquisition premiums Preussag paid were mostly unjustified. Bad luck like the events of September 11, 2001 cannot account for the poor performance of the stock. Poor management resulted from poor governance, combining a state-owned bank as the largest shareholder, board interlocks, and insufficient managerial incentives. The case shows how divestiture programs increase the liquid resources available to management beyond free operating cash flows and casts doubt on the positive governance role of institutional blockholders.
\end{abstract}

JEL classifications: G32, G34

Keywords: $\quad$ Corporate Governance, Large shareholders, Germany, Diversification, Mergers and Acquisitions 
Many managements apparently were overexposed in impressionable childhood years to the story in which the imprisoned handsome prince is released from a toad's body by a kiss from a beautiful princess. Consequently, they are certain their managerial kiss will do wonders for the profitability of the target company. We've observed many kisses but very few miracles. Nevertheless, many managerial princesses remain serenely confident about the future potency of their kisses even after their corporate backyards are knee deep in unresponsive toads.

Warren Buffet, Berkshire Hathaway Annual Report 1981

\section{Introduction}

At the beginning of fiscal year 1993/94, Preussag's sales were 4\% in logistics, 4\% in information technology, and 92\% in “old economy” lines of business, including metal trading, steel, mining, shipbuilding, and plant construction. At the end of 2004, tourism accounted for $73 \%$, logistics for $19 \%$, and nine of the ten “old economy” segments as well as information technology were gone. Moreover, the company had now relabeled itself "TUI AG," and only the identities of its CEO, its chairman of the supervisory board, its largest shareholder, and the registration code of its stock preserved continuity. From 1994 to 2004 the stock gained 9\% while the market index rose by $71 \%$ and an industry-weighted portfolio by $115 \%$. We track Preussag's history and the fate of its stock and analyze its 47 acquisitions and 46 divestitures as well as other transactions and news events. We find that Preussag's divestiture program was a success and added significant shareholder value. However, the investment of divestiture proceeds into tourism was misguided: Preussag lost value by investing in an industry it did not understand and, ultimately, by overpaying for assets to which it could not add any value. Or, extending Warren Buffet's famous parable, as Preussag kissed too many toads that failed to turn into princes, it ultimately became a rather unattractive toad itself.

This paper asks what went wrong in the process that turned Preussag, a traditional diversified conglomerate, into TUI, a modern and focused services company. In the process, we suggest some general conclusions about corporate governance, acquisition programs, incentives for voluntary liquidations, and the potentially ill-fated role of institutional shareholders.

We analyze three phases of Preussag's development:

Phase 1: From January 1, 1994 to June 10, 1997 Preussag's strategy was to restructure its core lines of business, expand the profitable segments and divest everything that was not profitable. This strategy looked promising initially but then delivered less than expected, and the stock lost $25.0 \%$ relative to the market index.

Phase 2: On June 11, 1997 Preussag bought Hapag-Lloyd, a company in container shipment, luxury cruises, airlines, and travel agencies. From then on until September 11, 2001, Preussag undertook altogether 16 acquisitions in tourism 
and divested most of its former lines of business. During this period, Preussag outperformed the market index by $29.6 \%$.

Phase 3: Beginning with the terrorist attacks on September 11, 2001, tourism went through a number of crises that marked a structural shift in the industry. Preussag slowed down its acquisitions and consolidated its tourism and logistics operations. Most restructuring was internal during this period, and the stock underperformed the market by 38.4\% until December 31, 2004.

Our main focus is on the second phase where Preussag entered tourism, as it presents the key to understanding the turnaround in the company's strategy. We group transactions into several categories, including "tourism acquisitions," "other acquisitions," and "sell-offs." We also analyze "tourism news" and "other news," mostly financial disclosures. We then conduct an analysis of variance of Preussag's stock return in order to distinguish the impact of different categories of news and announcements on the stock price. We also adapt event study methodology to our problem. Our main findings are:

- The positive performance in Phase 2 is explained entirely by Preussag's divestiture program. Divestitures themselves explain an outperformance relative to the stock market of $48 \%{ }^{1}$

- The positive impact of divestitures hides the value destruction through tourism acquisitions. These reduced the stock price by $35 \%$ relative to the index.

- The crises affecting tourism in Phase 3 cannot explain the underperformance of Preussag during this time.

We then calculate the value Preussag would have had if it had divested all its traditional businesses but not acquired any tourism companies. Had Preussag invested the proceeds from its sell-offs into a tourism and logistics index, rather than into tourism and logistics companies, then its shareholders would have almost tripled their wealth to more than $€ 11$ billion rather than seeing it reduced to $€ 3.3$ billion.

Preussag followed a strategy of "business migration" that only few other firms have followed before. ${ }^{2}$ The remarkable feature of Preussag remains the speed of their transformation, which mostly happened, between 1997 and 2001. Our analysis shows that

1 This and the following number measure performance relative to an index in logarithmic returns and refer to the calculations in Section 4.

2 Besanko, Dranove and Shanley (2000) cite the example of American Can, a maker of tin cans and metal containers, that became Primerica, a financial services company that acquired the US business of Barclays Bank and Smith Barney. Others include US Steel that became USX when it added oil to its steel business (without divesting steel), and International Harvester, a farm equipment manufacturer in the 1930s and 1940s, that became the truck manufacturer Navistar today (see Besanko, Dranove and Shanley, 2000, pp. 200-201). 
this strategy consistently destroyed large amounts of shareholder value and raises the question why such a strategy could be followed over an extended period of time without any interference by shareholders. We study Preussag's corporate governance and find that compensation was practically unrelated to performance and did not provide incentives for a voluntary liquidation of the company. Rather, compensation increased substantially as Preussag was transformed into Europe's largest tourism company. We also document that this strategy created significant private benefits in the form of increased status for Preussag's CEO as he accumulated seats on other companies' boards. At the first glance, a better alignment of management's and shareholder's interests could have been expected as Preussag had an independent supervisory board and a large controlling shareholder. However, it turns out, however, that the large shareholder was an intermediary - a stateowned bank - whose management had little incentive to prevent the destruction of shareholder value. This bank commanded almost complete control over Preussag through its voting power and interlocking directorates.

Our discussion of corporate governance and the causes of value destruction brings out four general points: (1) Managerial discretion is not limited to free operating cash flows, but also includes the (potentially much larger) proceeds from divestitures; (2) Large shareholders are a mixed blessing if they are institutions that suffer from agency problems themselves; (3) Compensation is critical to induce value-enhancing, voluntary liquidations; (4) Independent supervisory boards lose their bite in networks of cross-holdings and board interlocks.

The paper is structured as follows. Section 2 presents the details of the history of Preussag and background information on the major players. Section 3 introduces our data and the method of analysis. Section 4 contains the main results of our empirical analysis. Section 5 is devoted to an analysis of what went wrong at Preussag and puts the case into a larger context. Section 6 summarizes the reaction of Preussag's management to our results, and Section 7 concludes.

\section{Background and Stock Price History}

\section{History of Preussag}

Preussag's history dates back to 1924, when the "Preussische Bergwerks- und HüttenAktiengesellschaft” took over state-owned amber operations in Königsberg, turning Prussian civil servants into entrepreneurs. ${ }^{3}$ The first step towards privatization was taken with the 1959 IPO and the name changed to Preussag AG in 1964. Acquisitions in the 1960s created a diversified conglomerate with engagements in logistics, mining, oil 
exploration, metal production, and trading. In 1989 Preussag took over Salzgitter AG, a state-owned company in steel, shipbuilding, and engineering, creating a corporation with more than 70.000 employees.

\section{[Insert Table 1 about here]}

Table 1 provides data on Preussag's sales by segment and shows that in fiscal year 1992/93, their largest segment by revenues was trading (trading in steel and non-ferrous metals), which together with the related logistics operations accounted for $40 \%$ of sales. ${ }^{4}$ Plant construction with altogether 13 different activities (including nuclear power plants, civil engineering, underground engineering) prospered at this time because of the construction boom after German unification. Steel production was the third largest segment with $10.4 \%$ of sales. The Herfindahl index that measures the degree of diversification is 0.18 for this fiscal year, describing a moderately diversified conglomerate.

\section{Preussag's main shareholder: WestLB}

The major shareholder of Preussag during the entire period under consideration here is the Westdeutsche Landesbank Girozentrale (WestLB), who owned 29.1\% directly and another approximately 3.5\% indirectly through their 33.3\% stake in Niedersachsen Holding. WestLB was important for Preussag not only as its major shareholder but also through its portfolio of industrial holdings, especially in tourism. This becomes apparent from Figure 1A, which describes the major blockholdings in the Preussag-WestLB-network in 1994 that remained almost unchanged until June 1997.

\section{[Insert Figure 1 about here]}

WestLB is the fourth largest German bank by assets and also the largest state-owned bank in the country with its main regional focus in the state of North Rhine-Westphalia. ${ }^{5}$ The original purpose of WestLB was to assist small local savings banks to coordinate their liquidity. These savings banks are community owned and were founded to provide affordable banking services to small and medium size businesses and less well-off households. In addition, WestLB is a major lender to the state and to the communities of North Rhine-Westphalia. The owners of WestLB, the state of North Rhine-Westphalia and a number of communities, guarantee for all liabilities of the bank. In the 1960s, WestLB began to extend its scope and started to assemble a portfolio of stakes in German companies. Over subsequent decades, these included Preussag, Babcock and a number of

3 The name can be translated as “Prussian Mining and Steel, Inc.”; Königsberg is now Kaliningrad, Russia.

4 We do not have earnings figures by segment. German GAAP requires segment reporting for sales only.

5 Handelsblatt, December 3, 2001, p. 21. We rely on Handelsblatt for most of our company information. It is a German business daily newspaper with detailed company reports. 
major tourism companies (see Figure 1A). In the 1980s and 1990s, WestLB expanded into investment banking and leasing and built up a worldwide network of branches. WestLB made headlines in 2003 when its London branch lost about $€ 500$ million in a deal with the UK based TV rental company Boxclever.

\section{Phase 1: Consolidate core businesses (1994-1997)}

On January 1, 1994 Michael Frenzel, already a member of the management board for six years, became CEO of Preussag. During the first three years of his leadership, Preussag followed a strategy described as "value-oriented development." Its key focus was to “extend Preussag's core competencies in plant engineering and construction and technological services.” (Preussag, Annual Report 1993/94, p. 9). This strategy comprised the following parts: (1) Identify three segments for growth, (2) retain "core segments" with more limited growth prospects but sufficient profitability, (3) divest segments that have no potential for growth and are not profitable, and (4) accelerate internationalization by expansion into the Asian-Pacific region as margins in Western Europe stagnate. Following this strategy, Preussag sold the Hagenuk group, a manufacturer of mobile phones that suffered severe losses, and exited from railcar manufacturing. Apart from these segments, the relative weights of the other segments within the company did not change much until fiscal year 1996/97. Preussag undertook 11 acquisitions and 14 sell-offs from January 1994 to June 1997.

\section{[Insert Figure 2 about here]}

Figure 2A displays Preussag's stock price for this period. The figure shows the performance indices of Preussag's stock and of the CDAX, so dividends are always reinvested. The CDAX represents a value-weighted portfolio of all German corporations traded on the Frankfurt stock exchange. During most of the first phase, where Preussag's management tried to restructure their old economy businesses, the stock price tracked the development of the index closely, with some divergence becoming apparent in the second half of 1996. As of 1997, the German stock market index started a strong ascent, in line with other markets worldwide, which Preussag's stock followed only partially. Over the first phase until June 10, 1997, Preussag's stock increased by $27.6 \%$, which is $25 \%$ less than the CDAX performance over the same time period. Our analysis needs to address the question why Preussag underperformed the index in this phase.

\section{Phase 2: Enter tourism (1997-2001)}

On June 11, 1997 Preussag bid for Hapag-Lloyd AG and opened a new chapter in the company's history. Hapag-Lloyd celebrated its $150^{\text {th }}$ anniversary in the same year, which they dated to the foundation of the "Hamburg-Amerikanische Packetfahrt-Actien- 
Gesellschaft" (short "Hapag”) in 1847, which had opened its North Atlantic service (Hamburg-America-Line) in 1848. Its main focus is in global container shipping, airlines, travel agencies, and luxury cruises, four areas entirely unrelated to Preussag's traditional lines of business. Hapag-Lloyd was publicly listed but its free float was less than $1 \%$ of its shares. Hapag-Lloyd also owned a 30\% stake in TUI, which was a tour operator independent of Preussag (see Figure 1A).

With this takeover, Preussag entered the German tourism market that consisted of three main segments: tour operators, travel agencies and charter airlines. An integrated European tourism industry did not exist at that time. The tour operator market had a volume of about $€ 15.6$ billion in 1997 and had grown at an annual rate of almost 9\% since 1990. This market was highly concentrated at the time with the three major players being TUI (market share: 26\%), C\&N (22\%) and LTU (12\%). The German travel agency market grew by an annual 7.3\% between 1990 and 1998 and reached a sales volume of about $€ 22.5$ billion in 1997. During the previous decade the concentration in this segment had increased dramatically but was still only moderate. As a consequence of the aggressively expanding travel agency chains and the entry of new competitors, average industry return on sales decreased significantly from $10.1 \%$ in 1993 to $3.3 \%$ in 1996 . The three major players in this market are Hapag-Lloyd, First and C\&N with a combined market share of about 20\%. Finally, the charter flight market was also a fast growing segment during the 90's because of the increasing popularity of overseas holidays. Like the tour operator segment, this market is an oligopoly where the three major airlines are Condor/C\&N (24\%), LTU (24\%) and HapagLloyd (16\%). Clearly, the features of tourism as a growing market and the perceived general shift of the economy from manufacturing towards services made it look attractive compared to the stagnating, cyclical, and often loss-making traditional businesses Preussag operated before.

During this period, Preussag undertook 26 acquisitions (16 of which were in tourism) and 15 divestitures, mostly of its traditional lines of business. As a result, Preussag became more focused, and its degree of diversification fell significantly over this period. The Herfindahl index based on sales reached 0.38 in 2001, almost double the average value during 1994-1997. At the same time, WestLB disengaged from tourism, selling most of it to Preussag. Figure 1B depicts the ownership and cross-shareholdings at the end of 1999. The comparison to Figure 1C shows how acquisitions and divestitures disentangled this network in subsequent years.

[Insert Figure 3 about here]

Figure 2B shows that Preussag's stock appreciated by $44.8 \%$ over this period (until September 10, 2001), whereas the market as a whole rose by only 15\%. A potential 
explanation for this superior performance is that Preussag is just a high-beta stock that profited from the general rise in markets. Figure 3A disproves this conjecture. The chart shows the development of Preussag's beta from 1994 to 2004 measured over a moving 500 trading day window. This beta is highest at the beginning and at the end of the period (close to 1.0), but low in the middle phase between 1997 and 2001, where it falls into the 0.6-0.8 range. Hence, Preussag outperformed the market while moving its field of operations from "old economy" towards tourism. We therefore have to address the question why Preussag outperformed the market and whether this can be interpreted as an endorsement of its business model by the stock market.

\section{Phase 3: Consolidate tourism (2001-2004)}

After the terrorist attacks on September 11, 2001, tourism suffered a general setback. Subsequent events like the war in Iraq and the SARS epidemic in Asia reinforced these problems for many tourism companies. We therefore separate this third phase from the previous phase. After September 11, 2001, Preussag scaled back its acquisition program and undertook only 10 smaller acquisitions (9 in tourism) and continued to exit from its previous lines of business with a total of 17 divestitures. Their efforts were focused on consolidating and restructuring their tourism business. At the end of 2004, almost threefourths of their sales came from tourism and another $19 \%$ from logistics, raising the Herfindahl index for diversification to $0.58 .{ }^{6}$

Figure 2C shows that Preussag's stock price fell by $11 \%$ by the close of trading on September 11 in Frankfurt. While the CDAX fell in line with other stock markets, the decline for Preussag was sharper, underperforming the index by more than $20 \%$ within the first ten days of the attacks. However, the CDAX subsequently started a sustained recovery, finishing 2004 at 97\% of its value on September 10, 2001, whereas Preussag ended 2004 at less than $60 \%$ of its value on that day. Preussag's beta increased after 2000 to values around 1.0, so this cannot explain why Preussag declined more than the market. Preussag's low stock price nearly led to its exclusion from Germany’s major stock index, the DAX in 2004. It also led to takeover speculations when Morgan Stanley raised its stake in Preussag to $10 \%$ in July 2004, and WestLB repeatedly expressed its interest to sell its $31.4 \%$ stake in Preussag. In December 2004, WestLB sold a 10\% stake to a Spanish investor who is reportedly a close friend of Preussag's CEO Michael Frenzel. The remaining WestLB shares were placed with other Spanish investors and with European institutional investors. In Section 4.3 we investigate what caused the spectacular collapse of Preussag's stock price

\footnotetext{
6 Preussag changed its name to TUI, its former tourism subsidiary, on June 26, 2002, towards the end of the period under consideration here. Throughout the text, we still refer to the company as Preussag and ignore the change of name in order to avoid confusion.
} 
over Phase 3. Was it just bad luck from an unforeseeable negative shock that was entirely outside management's control as managers claimed? ${ }^{7}$ Or did the market - belatedly recognize the problems of Preussag's concept of an integrated tourism company?

\section{Data and Methodology}

\subsection{Data}

In order to collect a complete set of transaction announcements and news we searched for "Preussag," “TUI," and "Hapag-Lloyd” in five different databases. (1) The Genios Business database, which includes several major German newspapers and business periodicals; $^{8}$ (2) DGAP, a service that collects disclosures to regulators; ${ }^{9}$ (3) The press release database of TUI AG available from their website; (4) For the years 2003 and 2004 we also had access to Lexis-Nexis and searched this database for "TUI". ${ }^{10}$ Whenever we identified a transaction in any of these databases, we verified the names of acquirer and target with the Genios Business database. We also downloaded all transactions from Thomson Financial SDC where these companies appear either as target or as acquirer, but we found this database to be particularly unreliable. ${ }^{11}$ We therefore deleted all events from Thomson Financial that could not be confirmed from one of the other sources. These were only small and probably insignificant transactions, so we feel confident that this decision does not bias our results but that it significantly enhances the accuracy of our data.

As a general rule we assume that disclosures to the market happened one trading day before the publication date of the newspaper. For electronic disclosures we use the same day. In those cases where there is clear evidence (time stamp) that the news did not reach the market before the close of trading, we assign the event day to the subsequent trading day. We cannot exclude the possibility that we miss the correct event date by one trading day in some instances. We also searched the Genios Business database for news articles and press releases on industry news relevant to Preussag's businesses. In total, we can identify 125

7 Preussag, Annual Report 2003, p. 107. We refer to annual reports by fiscal year, not by publication date. For example, Preussag's annual report for the fiscal year 1994/95 was published in 1996.

8 These include the Wall Street Journal Europe, Handelsblatt, the M\&A Review, Tagesspiegel, Wirtschaftswoche, VDI Nachrichten, Der Spiegel, and Die Zeit.

9 DGAP is "Deutsche Gesellschaft für Ad-hoc Publizität $\mathrm{mbH}^{\text {“ }}$ and collects the disclosures to BAFIN (Bundeaufsichtsamt für das Wertpapierwesen), the German financial regulator (equivalent to the SEC in the US or the FSA in the UK).

10 Lexis-Nexis includes the Financial Times, Financial Times Deutschland, Börsen-Zeitung, Süddeutsche Zeitung, Die Welt, Frankfurter Allgemeine Zeitung, and Frankfurter Rundschau.

11 In many cases, the announcement date was confused with the effective date. In several other cases the announcement date was the publication date of the newspaper article even though exact time and date stamps for disclosures or company press releases existed. In more than $35 \%$ of the cases we had to correct the announcement date because it was evidently incorrect. This database was also highly incomplete. 
transaction announcements and 292 news items that we retain in our dataset, a total of 417 events.

We classify all announcements into the following five groups: tourism acquisitions, other acquisitions, sell-offs, tourism news, and other news. Whenever some ownership is transferred, we classify an announcement as an acquisition or a sell-off - irrespective of the percentage of ownership transferred in the transaction. Joint ventures to which Preussag mainly contributed cash and Preussag's partners contributed assets are classified as acquisitions. On the other hand, we regard the announcements of strategic alliances and joint ventures where Preussag does not contribute cash as a news item. Announcements of internal restructurings are also considered news items. Note that some transactions generate multiple announcements if they are executed in stages or if different pieces of news reach the market on different days. In total, we identify 62 announcements of 46 sell-offs and 63 announcements of 47 acquisitions, of which 25 were in tourism. Of the 292 news items, 44 regard tourism. Most of the others are disclosures of financial statements of Preussag and its subsidiaries.

We obtain stock market data from Thomson Financial Datastream. We choose the CDAX as the relevant market index. The CDAX represents a value-weighted portfolio of all German corporations traded on the Frankfurt stock exchange. All time series were adjusted for German holidays without stock market trading in order to avoid an underestimation of the excess returns' variance. Stock returns were calculated from the return index, which includes reinvested dividends.

\subsection{Methodology and Methodological Problems}

In order to test our hypotheses and address our questions, we analyze Preussag's stock price reaction in two different ways: (1) with a regression of Preussag's returns on dummy variables, and (2) with an adaptation of standard event study methodology. For our analysis, we use log returns, because log returns are additive over time and facilitate the attribution of returns to classes of events.

\section{Choice of benchmarks}

For both methods, a benchmark for the normal or expected performance must be chosen first. For Preussag, this turns out to be a major methodological problem, because the correlation of Preussag's shares with the market index varies markedly over time as Figure 3A demonstrates. Even within each of the three subperiods we defined above, Preussag's CAPM beta is not constant. On the other hand, 417 events in 11 years render it impossible to find enough 'clean' estimation windows for estimating the model separately for each event. We therefore work with the market adjusted model and simply deduct the market 
return (CDAX) from Preussag's return in order to arrive at Preussag's abnormal return. Brown and Warner (1985) show in a simulation study that the size and power of tests based on the market-adjusted model are only marginally worse than tests based on the market model.

We also employ an industry-adjusted model, where we subtract the return on an appropriately weighted industry index from Preussag's returns when calculating Preussag's abnormal returns. This industry-adjusted model helps us distinguishing between industry effects and firm-specific effects, because industry effects do not 'wash out' as in standard event studies based on firms from many industries. Since Preussag's activities moved more and more from steel and engineering towards tourism and logistics, we construct two industry indices: The steel and engineering index is an equally weighted portfolio of the FTSE Europe steel and other metals index and the FTSE Europe engineering and machinery index. The tourism and logistics index is an equally weighted portfolio of the FTSE Europe leisure and hotels index and the FTSE Europe transport index. Figure 3B displays the coefficients of a regression of Preussag's daily returns on the corresponding returns of these two indices and an intercept where the regression is performed over a moving 500 trading day window. Both series start in January 1995, because the FTSE Europe indices are not available before January 1994. The plot demonstrates that the correlation between Preussag's returns and the returns on the tourism and logistics index steadily and markedly increases over the period considered while the correlation with the steel and engineering index decreases. The plot therefore reflects the transformation of Preussag from a steel and engineering conglomerate to an integrated tourism and logistics service provider.

As Preussag gradually moves from one industry to another, we construct a weighted industry index for use in the industry-adjusted model. A similar approach has been used by Parrino (1997). We weight the 'steel and engineering'-index and the 'tourism and logistics'-index with the total assets of each segment according to the most recent balance sheet. $^{12}$ The weight on 'tourism and logistics' rises steadily from 3.1\% in 1994 to $97.6 \%$ in 2004.

\section{Regression approach}

For each of the three time periods, we regress the daily abnormal returns $A R_{t}$ on an intercept and on up to six dummy variables $D_{i, t}$ that are set equal to one for every day $t$ within the event window for an event of type $i$. So if type 1 represents sell-offs, the event

\footnotetext{
12 We could not obtain total assets for segments prior to September 30, 1998, so we use sales as a weight before that date. We use sales numbers excluding intra-company sales for computing these weights. These sales figures differ from those reported in Table 1 where intra-company sales are included.
} 
window is $[-1,0]$, and a sell-off was announced on day $\tau$, then $D_{1, \tau-1}=D_{1, \tau}=1$. The regression equation is:

$$
A R_{t}=\hat{\alpha}+\sum_{i=1}^{6} \hat{\beta}_{i} D_{i, t}+\hat{\varepsilon}_{t}
$$

Here $\hat{\alpha}$ and the $\hat{\beta}$ 's are estimates of the regression coefficients and $\hat{\varepsilon}_{\mathrm{t}}$ the OLS residuals. This regression approach has been widely used in the literature. (See Binder, 1985, for a comparison with the standard event study method.) In the context of a clinical study, the regression approach has been used by Bittlingmayer and Hazlett (2000). By summing equation (1) over all observations $t$, we obtain:

$$
\sum A R_{t}=n \hat{\alpha}+\sum_{i=1}^{6} n_{i} \hat{\beta}_{i}
$$

where $n$ is the number of observations used in the regression and $n_{i}$ is the number of observations for which the dummy variable $D_{i}$ equals one, i.e. $n_{i}=\sum D_{i, t}$. Note that the sum of the residuals $\hat{\varepsilon}_{t}$ is zero as these are OLS residuals. In Tables 2, 4, and 6, we report the cumulative effects $n_{i} \hat{\beta}_{i}$ rather than the average effects $\hat{\beta}_{i}$, because we want to quantify the total impact of the different components of Preussag's strategy.

\section{Event study approach}

Our second approach is based on standard event study methodology. We calculate cumulative abnormal returns (CARs) for a small event window around each event individually and then add the CARs of events of the same type (sell-offs, tourism acquisitions, etc.) in order to test more general hypotheses. We use the same classes as in the regression analysis.

As we consider 417 announcements during a total of 2,775 trading days, we naturally encounter overlapping event windows and even multiple events per day. When we add up cumulative abnormal returns across events within one class, such overlaps become a serious methodological problem. We address this problem by introducing "multiple events" and "no events" as additional classes. After putting the event windows around the individual events, we assign each trading day to exactly one class. Each day that belongs to two or more event windows of different classes is assigned to the class "multiple events." All other days that fall into one of the event windows are assigned to the class of the respective event. Finally, each day that does not belong to any event window is classified as "no events." From the days in the "no events" class, we calculate the standard deviation of abnormal returns used for significance tests. In order to conserve space, we report our event 
study results only for Phase 2, which is the key time period in our analysis. The results of the event study approach and the regression approach are very similar.

\section{$4 \quad$ Analysis and Evaluation \\ 4.1 Phase 1: Consolidate Core Businesses (January 1, 1994 - June 10, 1997)}

The first three and a half years of Michael Frenzel's tenure at the helm of Preussag are marked by his attempt to turn the company around through a restructuring program described as "value-oriented development."

[Insert Table 2 about here]

Table 2 contains the regression results from equations (1) and (2) for this period. The table displays the part of the total abnormal return that can be explained by three event groups: acquisitions, sell-offs, and news. Results are presented for four different event windows and two choices of the benchmark index. The main findings from Table 2 are robust to the different test specifications. Abnormal returns in all transaction categories are small and statistically and mostly also economically insignificant. Only the 67 news announcements with one exception all disclosures of financial statements about Preussag and its subsidiaries - are highly significant and negative. Altogether, it seems that the decisions of Preussag's management during the period 1994-1997 held little surprise for the stock market. However, financial disclosures were mostly negative and resulted in a cumulative underperformance of $22 \%$ to $43 \%$ over the whole period. ${ }^{13}$ Hence, Preussag consistently surprised the market with less than expected financial performance.

As Preussag outperformed the market for the whole of 1994 by $12.0 \%$ (actual return), we conclude that the stock market initially subscribed to Preussag's concept of a "value oriented" restructuring, and the transactions of the company were clearly geared towards this goal. Then the market slowly and steadily absorbed the less than promised impact of this strategy as it became reflected in Preussag's financial performance, and completely lost heart in 1996: during that year, Preussag underperformed the CDAX by 58.4\% (actual return). From this perspective, it is not surprising that Preussag's management began to rethink its strategy at the beginning of 1997.

\subsection{Phase 2: Enter Tourism, Exit Core Businesses (June 11, 1997 - September 10, 2001)}

The second phase begins on June 11, 1997, when Preussag confirmed previous rumors that it bid for Hapag-Lloyd. This event marked a turning point, as tourism now became a major

\footnotetext{
13 All returns given in Sections 4.1 through 4.3 are log returns if not stated differently.
} 
part of the company's activities, accounting for $28 \%$ of sales in fiscal year 1997/98, and for $57 \%$ in fiscal year 2001 (see Table 1).

[Insert Table 3 about here]

Table 3 lists abnormal returns and short descriptions for the main events during phase 2 of our analysis. The first rumors regarding Preussag's intention to buy Hapag-Lloyd circulated already on May 27 without moving the stock price. The announcement of the takeover itself on June 11 led to a statistically insignificant increase of Preussag's share price. The final price of $€ 532$ per share - a 14\% premium on the pre-announcement price - was announced only after negotiations concluded and became public on September 2, which led to a significant decline in Preussag's stock. It is therefore difficult to discern from this an unambiguous reaction of the stock market to Preussag's change of strategy, and the negative reaction to the last announcement may well imply that Preussag simply overpaid. It is certainly not clear how Preussag could justify a $14 \%$ premium for the purchase. As recently as 1996 Preussag had argued that its core competencies were in logistics, steel, and oil (Annual Report 1994/95, p. 9). Now they announced the transformation of the company into a "modern services company” (press statement dated September 3, 1997).

Hapag-Lloyd also owned 30\% of the tour operator TUI (Touristik Union International), and Preussag CEO Frenzel was quoted in the press on June 12, a day after announcing the bid for Hapag-Lloyd, that they were also interested in acquiring another 30\% stake from WestLB in order to obtain majority control. Clearly, the Hapag-Lloyd takeover set the stage for a stronger engagement in tourism and services. Industry observers, including the federal cartel office, Germany's antitrust regulator, perceived the emergence of a duopoly for the German holiday market with Preussag, Hapag-Lloyd and LTU on one side, and C\&N with its holdings Condor and NUR as their only main competitor on the other side. The later purchases of the other TUI stakes from Deutsche Bahn, the state-owned German railway operator, and the Schickedanz group (see Table 3) was probably anticipated by the market and did not cause significant movements of Preussag's stock price.

With the acquisition of Thomas Cook, a large British tour operator, travel agency chain and financial service provider, Preussag's expansion into tourism reached an international dimension. On October 9, 1998, the press reported rumors about Preussag's ambitions to buy Thomas Cook for the first time. At that time, Thomas Cook planned to merge its activities with the British interests of US-based Carlson Companies, Inc. The decision became official only in December, but evidently the stock market took this announcement seriously and reacted enthusiastically with the CAR measured over the $(0,2)$ event window reaching 9\%. The staged acquisition of Thomas Cook from WestLB (a 24.9\% stake in December 1998, followed by another $25.2 \%$ in September 1999) itself did not cause the 
stock price to move. Evidently the purchase price was more in line with the market's expectations in this case. The reaction to the first announcement suggests either that the market endorsed Preussag's move into tourism at this time, or that WestLB sold Thomas Cook to Preussag for too low a value. WestLB is not listed, so we can only look at the return to this investment for Preussag as they sold Thomas Cook at a premium in December 2000. The internal rate of return from their investment is $74 \%$ when the stock market gained only $23 \%$ over the same period. ${ }^{14}$ This favors the hypothesis that WestLB sold Thomas Cook to Preussag at a discount.

In 2000, Preussag increased their engagement in the UK and consolidated their investment in tourism by purchasing Thomson Travel Group plc, the largest UK tourism group. Before Preussag became interested, Thomson Travel had been engaged in negotiations with C\&N about a merger during April 2000. C\&N had bid first 130 pence and then 145 pence per share for Thomson Travel, which put a price tag of $€ 2.42$ billion on Thomson Travel. On April 12, 2000, Frenzel discussed this development at Preussag's annual general meeting and described this price as "extremely high." He expressed "no interest" at the time and said Preussag's attitude to this regrouping of their competitors as "extremely relaxed." Exactly one month later, on May 15, 2000, C\&N had increased its bid to 160 pence per share (€2.67 billion) when Preussag announced that it would top the C\&N-offer with a spectacular 180 pence per Thomson Travel share ( $€ 2.8$ billion), about twice its valuation before takeover rumors first reached the market. ${ }^{15}$ Frenzel now argued that Thomson is "a British TUI" that would offer Preussag "the chance for a quantum leap for the expansion of its tourism operations" and a "unique opportunity." Industry commentators were less impressed, pointing out the lack of synergies, Thomson's meager sales margin (3\% compared to an industry average of $4 \%$ ), the fact that Thomson had lost almost half of its 170 pence per share value after its IPO in May 1998, and the fact that EU competition authorities would require Preussag to divest Thomas Cook again in order not to obtain too strong a position on the British market. ${ }^{16}$ The stock market clearly took a negative view. All CARs reported in Table 3 for the date first rumors became known (Friday, May 12) and on the subsequent official announcement (Monday, May 15) are significantly negative at the 1\%-level. As these event windows overlap, the most informative statistic is the cumulative

14 Preussag paid $€ 146$ million for the first stake on December 23, 1998 (M\&A Review, 2/1999, p. 101) and $€ 147$ million for the second stake by exercising their purchase option on September 30, 1999. They sold all their holdings on December 5, 2000 for $€ 461$ million (Handelsblatt, December 8, 2000, p. 22).

15 The precise measurement depends on the reference date, which is difficult to determine, as there was a run-up as early as March and April 2000. This run-up was possibly caused by rumors in the market, but a part of it may be attributed to fundamental information about Thomson. The stock price on the date before C\&N’s first offer was 95.25 pence. Preussag’s bid premium was $89 \%$ relative to this price.

16 Handelsblatt, May 16, 2000, p. 2, and Wall Street Journal Europe, May 16, 2000, p. 4 
abnormal return from May 11 to May 17, which is $-15.3 \%$ representing a loss of $€ 1.19$ billion of Preussag's market capitalization. This is approximately equal to the premium $€ 1.23$ billion Preussag paid for Thomson Travel on the pre-takeover price, so none of the synergies and economies of scale emphasized by management seemed to justify such a premium from the market's point of view and this sum simply represented a transfer of wealth from Preussag's shareholders to Thomson Travel's shareholders. On May 15 Preussag also published interim semi-annual financial reports, but these were wholly favorable, above the previous year's results and in line with the market's expectations, so we classify May 15, 2000 as a tourism acquisition and disregard the financial statements as a potentially disturbing event.

[Insert Tables 4 and 5 about here]

Table 4 reports the regression results for the period from the Hapag-Lloyd announcement up to and including September 10, 2001. Of the 29 tourism acquisition announcements, 16 are also listed in detail in Table 3. We distinguish purchases from WestLB (6 announcements) from all other tourism acquisitions (23 announcements) and find that purchases from WestLB generate a cumulative positive $9 \%$ to $16 \%$, whereas all other tourism acquisitions lead to a cumulative abnormal returns of $-17 \%$ to $-52 \%$. Table 5 displays the corresponding event study results that are similar in magnitude but generally show somewhat higher levels of significance than the regression results in Table 4. Table 5 also demonstrates that all tourism acquisitions together result in a cumulated loss of value between $10 \%$ and $35 \%$, although this is often statistically insignificant. ${ }^{17}$ Results become significant, however, once we distinguish between purchases from WestLB and other purchases. Hence, purchases negotiated under market conditions generated highly significant negative returns, whereas the "friendly" purchases from WestLB (in particular the acquisition of Thomas Cook) where favorable for Preussag. This finding is consistent with the general observation that tender offers and bidding competition generally create lower and mostly negative bidder returns compared to prices established through bilateral negotiations. For example, in a study of bidders that make multiple acquisitions, Fuller, Netter, and Stegemoller (2002) find that returns to the acquisition of public targets are significantly lower than those to the acquisition of privately held firms or subsidiaries (controlling for the identity of the bidder). Altogether, we therefore conclude that entering

\footnotetext{
An advantage of the event study method is that the two classes "Tourism acquisitions from WestLB" and "Other tourism acquisitions" can be merged without changing the results for the other classes of events. For Phases 1 and 3, the event study method and the regression method yield quantitatively very similar results. Generally, the event study results turn out to be slightly more significant than the regression results. We therefore do not present the event study results for Phases 1 and 3.
} 
tourism destroyed shareholder value. In total, Preussag's shareholders paid a price of $€ 0.402$ - $€ 1.343$ billion for this change of strategy. ${ }^{18}$

As the stock price of Preussag increased relative to the market index during the 1997-2001 phase, we now need to understand where the increase in wealth came from if not from a successful engagement in tourism. Tables 4 and 5 suggest that there was another part of Preussag's strategy in this period that seemed to be uniquely successful: the divestiture of its former core businesses in steel, non-ferrous metals, plant construction, and building engineering. 25 sell-off announcements fall into this period, 7 of which are listed in Table 3. The cumulated return to these sell-offs is positive and large overall and often highly significant. The reason for these sell-offs was to obtain money for further investments in tourism and logistics as it appears that Preussag paid cash in all its acquisitions. ${ }^{19}$ Other news also had a significant impact on Preussag's stock price as Table 3 shows. Since the market reaction is sometimes positive and sometimes negative, the aggregated effect of 'other news' shown in Tables 4 and 5 is not significant.

Our main conclusion is therefore that Preussag's management generated considerable value for its shareholders during the period from 1997 to 2001 by divesting their former lines of business. Unfortunately, they did not pay out the proceeds to their shareholders but reinvested them in the acquisition of tourism companies instead. The market did not grant Preussag's management any specialized skills in this area and seemed to subtract the takeover premiums they paid - notably in the disastrous acquisition of Thomson Travel one for one from their market value. At the end of this phase, Preussag was mainly a focused tourism and logistics group. At that point, the terrorist attacks of September 11, 2001 brought the period where tourism was a growing, profitable industry to an immediate halt.

\subsection{Phase 3: Consolidate Tourism (2001-2004)}

In the period between September 11, 2001 and December 31, 2004, Preussag underperformed the CDAX by $49.8 \%$. Was the poor performance of Preussag's stock just bad luck? We approach this question in the same way as before.

[Insert Table 6 about here]

Table 6 displays our regression results for this period. Clearly, no category of events accounts for significant stock price changes in one direction or another. Interestingly,

18 For this comparison, we use the numbers from Table 5, Panel A and multiply the CARs with the market capitalization on June 10, 1997 of $€ 3.892$ billion.

19 There is no source to confirm this but none of the news sources we studied ever mentions stock or other securities as acquisition currency. The same holds true for all sell-offs except their shipbuilding and plant construction to Babcock, where they accepted Babcock shares in return. 
"tourism news" as a group is insignificant over this period. Preussag's stock lost 33.1\% (actual return) within the first 10 days after September 11, an underperformance of the index of $20.6 \%$ (actual return). However, this and subsequent events like the Iraq war were later compensated by positive news and reassessments by the market. This picture is confirmed by looking at the industry-weighted index, which controls - at least partially for tourism-specific events. Table 6 shows that the magnitude of "tourism news" is always smaller for the weighted industry benchmark than for the CDAX. In fact, Preussag's cumulative abnormal return relative to this index was $-81 \%$, indicating that more must be at work here than just a bet on tourism that went wrong ex post. Most of the underperformance during this period falls into the category "unexplained returns," i. e. those days where no particular event or news item can be found from any of our sources of information. ${ }^{20}$ Note that during this period, the German stock market underperforms the European stock market. The industry-weighted index (in Phase 3 largely tourism) is a European index with a stronger performance than the German market but weaker than the European market at large. Preussag underperformed all of them.

During this period, Preussag's management reacted with standard retrenchment measures. They tried to cut costs in its tourism operations, and to experiment with new products and distribution channels. During 2002, these efforts neither showed any visible success nor did they show which direction management intended to take. For example, on June 19, 2002 they announced a new brand to sell last minute holidays, imitating a strategy of their competitor $\mathrm{C} \& \mathrm{~N}$. On October 10 of the same year they announced an expansion of their luxury segment, arguing that it had higher margins. Neither announcement impressed the stock market.

In 2003 Preussag (now renamed TUI) announced a new brand "Discount Travel” to expand its franchise in the budget travel market, and was rewarded with an $8.8 \%$ increase of its stock price on the same day. However, a few days later Frenzel announced a "restructuring” (effectively shrinking) of the management board that also included the dismissal of both tourism specialists on the board without replacement. Analysts were mostly outraged by the prospect of having Europe's largest tourism company led by a management without any tourism expertise and downgraded the stock. Preussag lost almost $12 \%$ of its market value as a consequence.

20 We were skeptical that this could be true and went back to search for news on dates of large stock price movements. We found one announcement in Phase 2 related to speculations about a reweighing of the DAX. On other dates, all of them in Phase 3, market commentators talked about "revaluations" without being able to point out significant new information. We discuss press and analysts' coverage in Section 5.2 . 
Overall, Preussag's management struggled with the impact of an increasingly hostile environment after September 11, 2001 - as did most tourism companies. They tried to cut costs, strengthened the luxury segment and later the low cost segment of their operations, fired managers and reorganized internally. Still, the stock market turned its back on the company more than it did on its competitors. Ultimately, the business model of Preussag did not convince the market.

\subsection{Overall assessment}

Preussag's decision to shift gears in 1997 and to give up on their original restructuring plan was well motivated given that previous efforts did not have the desired impact on their performance. However, choices other than simply continuing to struggle with their traditional lines of business or entering tourism were clearly available. In this section we investigate one particular alternative more closely that is suggested by our analysis of Phase 2: simply liquidate the company and pay out the funds to shareholders. Naturally, as mature industries stagnate and shrink, some companies need to exit these markets, and if their managers do not have skills to add value in another industry, then the company should simply liquidate itself. We analyze the following strategies: ${ }^{21}$

1) Execute Preussag's divestiture program precisely as they did during the period 19972004. On September 30, 1997, use all cash available at that time to pay off debt and invest the remaining cash in our tourism and transport index. ${ }^{22}$ Use all subsequent proceeds from sales of businesses and invest them in the same index on the date of the sale. Similarly, whenever any of the traditional businesses generate free operating cash flows, invest those in the same way. We attribute these cash flows to the last day of the fiscal year. This strategy assumes the position of an investor who wants to invest in tourism and logistics rather than in metal trading, shipbuilding and Preussag's other businesses. However, this investor would put her money into a broad portfolio of logistics and tourism companies rather than those chosen by Preussag. Table 7 shows that this would have generated a balance of $€ 11,372$ billion on December 31, 2004.

2) Proceed as under 1 , but now reinvest cash, free operating cash flows, and sales proceeds from sell-offs in the CDAX. This assumes the position of an investor who simply wanted to exit from Preussag's businesses and put the money into a broad stock market portfolio. This strategy would have generated a balance of $€ 9,206$ billion.

21 In order to estimate exact values for the different strategies we did not use log returns, but actual returns for calculating the index returns. This ensures comparability with the actual history of Preussag's stock until December, 31, 2004.

22 It would be preferable to start this analysis on June 10, 1997 but we are limited to balance sheet data available for the end of the fiscal year 1996/97 and cannot base this analysis on events before that. 
3) Assume the company could have been sold to another investor on June 10, 1997, who would then have proceeded as he wished. Assume the sale price would have been the market value on that date, which was $€ 3.892$ billion, then reinvest these proceeds in the stock market. In this scenario, an investment in the tourism and transport index would have generated $€ 5.794$ billion by the end of 2004 .

4) Proceed as in 3), but now reinvest in the CDAX. Then the resulting value at the end of 2004 would have been $€ 4.495$ billion.

[Insert Table 7 about here]

Preussag's value (including reinvested dividends) was in fact only €3.333 billion at the end of 2004. The following table compares the results from the four alternatives described above to the actual result:

\begin{tabular}{|c|c|c|c|}
\hline Strategy & Description & $\begin{array}{c}\text { Value (bn) on } \\
\text { December 31, } 2004\end{array}$ & $\begin{array}{l}\text { Change to } \\
\text { status quo }\end{array}$ \\
\hline 0 & Actual history (status quo) & 3.333 & - \\
\hline 1 & $\begin{array}{l}\text { Liquidate as in history, reinvest } \\
\text { proceeds in tourism and transport } \\
\text { portfolio }\end{array}$ & 11.372 & 8.039 \\
\hline 2 & As (1), reinvest in CDAX & 9.206 & 5.873 \\
\hline 3 & $\begin{array}{l}\text { Invest the market value of } \\
\text { Preussag in tourism and transport } \\
\text { portfolio }\end{array}$ & 5.794 & 2.461 \\
\hline 4 & $\begin{array}{l}\text { Invest the market value of } \\
\text { Preussag in CDAX }\end{array}$ & 4.495 & 1.162 \\
\hline
\end{tabular}

The high values for strategies 1 and 2 compared to strategies 3 and 4 reflect the value created through the redeployment of assets. It shows that Preussag's exit strategy was successful. With hindsight, they were even correct in betting on tourism and logistics, as the portfolio reflected in our tourism and transport index outperformed the CDAX by 33\% over the period from June 10, 1997 to December 31, 2004. However, Preussag's management should never have undertaken these investments themselves, as their actual strategy destroyed more than $€ 1.1$ billion relative to a passive investment in the stock market, and more than $€ 8$ billion relative to the optimal strategy of liquidating the company and leaving it to shareholders to use the proceeds to invest in tourism and logistics companies. Ultimately, this is the range of values lost by Preussag's shareholders, and, in the final conclusion, by the German taxpayer who participated in this enterprise by virtue of WestLB's shareholdings. WestLB sold its stake in Preussag in December 2004 for €950 million. Therefore, given our four alternative strategies above, $€ 0.4$ billion to $€ 2.6$ billion of German taxpayer's money was wasted by the disastrous strategy of Preussag's management. Interestingly this enormous destruction of taxpayer's wealth was never 
discussed in the press. The issue was also never raised in the state parliament, presumably because the extent of the value destruction was not apparent. Some newspapers even reported that WestLB was able to realize a book profit (see e.g. Frankfurter Allgemeine Zeitung, December 2, 2004, p. 15).

\section{$5 \quad$ Why things went wrong - the larger context}

In this section we wish to understand why the story of Preussag could develop as it did. We therefore analyze decision-making and corporate governance at Preussag. We also put the case of Preussag into a larger context and draw more general conclusions.

\subsection{The Agenda of Preussag's Management}

When Preussag's management shifted the company's strategy to tourism in 1997, they explained this move in a letter to the shareholders as part of a "comprehensive modernization of Preussag” and they motivated the focus on tourism as "an industry with sustainable growth prospects.” (Preussag, Annual Report 1997/98, pp. 7-8). However, efficient markets would discount the higher growth prospects of tourism companies into their prices and we therefore need to ask how Preussag could justify any acquisition premiums. Preussag's move towards focusing is in general agreement with the notion that diversification destroys value, but Preussag was focusing on something unrelated to its former business. $^{23}$

Preussag developed the concept of a vertically "integrated tourism company" that would control all stages of the value chain from travel agencies to airlines and hotels. ${ }^{24}$ Their argument was that travel agencies would help to divert tourists to company-owned hotels and airlines and thereby increase capacity utilization. Standard arguments in industrial organization suggest that vertical integration may be helpful in overcoming hold-up problems or inefficiencies from double marginalization, but none of these advantages seems to be present here as all segments of the tourism market - with the exception of airlines - feature either a large number of suppliers, or low costs of entry and unspecialized assets (see Section 4.2). When market relationships dominate, standard textbook analysis emphasizes the costs of integration, as integration increases the scope for agency costs and influence activities and prevents the full exploitation of scale and learning economies. These arguments are never reflected in Preussag's press releases or annual reports.

\footnotetext{
23 See Martin and Sayrak (2003) for a survey of the literature on diversification and its consequences. Some authors argue that the diversification discount is not caused by diversification (see Graham, Lemmon, and Wolf, 2002, and Villalonga, 2004). Moreover, results for Germany indicate a lower diversification discount than for the U.S. (Lins and Servaes, 1999).

24 Annual report 1996/97 p. 8, Annual report 1997/98 p. 8 and pp. 23, 38, 89.
} 
The bid for Thomson Travel was inconsistent with Preussag's proclaimed strategy. At the time Preussag already had a significant stake in the British market with Thomas Cook. However, Thomson Travel was significantly larger and would otherwise have been acquired by $C \& N$, Preussag's smaller German competitor. Frenzel was possibly frank about his true ambition when he commented that this acquisition " $(. .$.$) secures our position as the$ biggest player in Europe” (Wall Street Journal Europe, May 16, 2000, p. 4). Exactly why size would matter for a tourism company and how size could be translated into value creation was never explained. The large number of small tourism companies suggests that economies of scale are limited, and academic studies show that the benefits from mergers and acquisitions do not derive from building market power (see Ravenscraft and Scherer, 1987, Mueller, 1985, and Eckbo, 1992).

Our analysis suggests that Preussag's migration from steel and mining to tourism was not the outcome of a well-formulated strategic concept but the result of the ambitions of its management, for which shareholders ultimately had to pay the price. At this stage it appears that Preussag's strategy corresponds more to what Roll (1986) described as "hubris," namely the tendency of corporate managers - epitomized in Warren Buffet's quote at the beginning of the Introduction - to overbid for companies they want to control. ${ }^{25}$ Before we subscribe to this view we investigate if Preussag's strategy generated benefits for its management in Section 5.3.

\subsection{The Role of Analysts and the Press}

The press and analysts paid close attention to Preussag's dramatic transformation and here we would hope for some more detailed critical comments that would emphasize the risks and downsides in Preussag's strategy. In order to compile our dataset we analyze a total of 2,000 newspaper articles and press releases but find little to this effect before 2003, and nothing in the phase before 2000. The press and analysts commented repeatedly on tourism as a "new growth area" that would offer new opportunities to Preussag in comparison to its traditional businesses, and Preussag became a model case of "business migration." Comments by Olaf Toelke, an analyst with Merrill Lynch (Frankfurt) are exemplary when he writes: "The company has come out of its cyclical corner and is now growth-oriented."26 Stock market analysts apparently supported Preussag's move to become more focused on tourism and to leave its former core businesses behind. The fact that Preussag's management focused on an industry they did not know before received little attention.

For empirical evidence on the hubris hypothesis see e. g. Raj and Forsyth (2003) and the earlier literature cited by them.

26 The Wall Street Journal Europe, February 2, 1999. The term "business migration” was explicitly used in the press, see Handelsblatt, February 10, 2000, p. 56. 
Our analysis has shown that Preussag's stock outperformed the market during 1997-2001 only because of its divestitures, but many commentators and analysts argued otherwise. In fact, when the stock price took a dip in early 2000, a major newspaper argued, "tourism increases the stock price” and even attributed the recent price drop to Preussag's failure to undertake more acquisitions. ${ }^{27}$ Obviously, analysts did not realize that Preussag outperformed the general stock market in spite of its investments in tourism and not because of them. This raises the issue of the status of analysts, as they were not only unable to convince investors of their analysis, but even failed to understand market signals correctly.

\subsection{Executive compensation and private benefits}

Board seats on other companies. Our first hypothesis is that managers must have gained from the strategy change at Preussag, either through increased compensation or through private benefits. German companies do not disclose itemized private benefits as US companies do, but a measurable indicator of private benefits is the status and prestige conferred on the CEO in the form of additional board seats of other companies. Michael Frenzel is Preussag's CEO during the entire period under consideration here. He joined Preussag's management board in 1988 at age 40 and became CEO in 1994 at age 46. Previously, he had spent seven years at WestLB, Preussag's major shareholder, where he was responsible for managing WestLB's blockholdings in industrial companies. In 1997/98 Frenzel holds board memberships in seven mostly smaller companies ${ }^{28}$, three of which are only subsidiaries and another three are state-owned. Over the following seven years, he gives up these seven positions and becomes board member in seven other, bigger firms, including two of Germany's top 30 listed companies. ${ }^{29}$ He is also chairman of the board of Germany's state-owned railway operator, and of one of Germany's ten largest banks. During this time Frenzel benefited particularly from his close relationship to his mentor Friedel Neuber, chairman of Preussag's supervisory board and CEO of WestLB (see Figure 1A). He followed him into the supervisory board of at least three companies, where Neuber was on the supervisory board before him. ${ }^{30}$ Frenzel also seemed to be in demand for CEO

27 Handelsblatt, February 18, 2000, p. 16, quoting Christian Obst (an analyst with Hypo-Vereinsbank) and Rolf Geck (analyst with WGZ-Bank).

28 Deutsche Hypothekenbank AG, IVG Holding AG, PreussenElektra AG, Creditanstalt AG, Kreditanstalt für Wiederaufbau, Hamburgische Landesbank, Expo 2000 Hannover GmbH.

29 AXA Konzern AG, Continental AG, Deutsche Bahn AG, Volkswagen AG, Norddeutsche Landesbank, E.ON Energie AG, ING Bank Deutschland AG.

30 Neuber was on the board of Deutsche Bahn AG from 1997- 2004, Frenzel follows 1999; Neuber is on the board of AXA S. A. from 1997- 2001, Frenzel joints AXA Colonia AG's board in 1998, Neuber was on the board of Bank Austria AG from 1997 - 2000, Frenzel is on Creditanstalt's (acquired by Bank Austria in 1998) board. In all cases we provide the earliest date of board membership we can establish, so board membership may have existed before. 
positions at other German companies. ${ }^{31}$ We can therefore conclude that during the period 1997-2004 Frenzel gained significantly in terms of status and prestige and potentially also in terms of his value in the market for managerial labor. This raises a more general question. Some authors, going back to Fama (1980), argue that the market for managerial labor acts as a check on managerial discretion, because managers will not exercise this discretion to the disdadvantage of shareholders in order not to reduce the value of their own human capital. Our analysis casts doubt on Fama's theory being an accurate description of the German market for managerial labor.

Executive compensation. German companies do not have to disclose individual salaries or compensation plans and we only have data on the total compensation of the management board and can therefore only infer averages. Table 8 illustrates that management board members received an average fixed salary of $€ 630,000$ - $€ 650,000$ annually during the period 1994-1997, which puts it significantly above the average for German corporations with more than $€ 1$ billion sales, which was $€ 420,000$ in 1996 (see Schwalbach, 1999). After 1997, compensation increases dramatically as this fixed salary is complemented by "performance related" pay. This is a $€ 500,000$ of bonus dependent on dividend payouts and a phantom stock scheme, where managers can sell phantom shares at the actual share price after a vesting period of two years. ${ }^{32}$ Management board members received $€ 7.7$ million worth of phantom stock during 2001-2003 that lost approximately €3.4 million during the same period. ${ }^{33}$ As a result, the average salary of Preussag's management board members increased by $279 \%$ from $€ 526,000$ in fiscal year 1993/94 to €1,992,000 in fiscal year 2004 (see Table 8). ${ }^{34}$ Therefore, while Preussag's shareholders did not benefit from the company's tourism strategy, its management certainly did. The overall increase in compensation can rationalize why Preussag's management was concerned with size. While the company did not increase in value, it did increase in sales and total assets (see Table 1 for sales, the development of assets is similar). This is consistent with the general result that managers benefit from acquisitions when these increase size and thereby lead to higher managerial salaries. This view can be dated back to Baumol (1959) and evidence for the U.S. was found by Khorana and Zenner (1998).

[Insert Table 8 about here]

31 RWE (Die Welt am Sonntag, April 28, 2002), where Neuber is chairmen of the supervisory board, and Deutsche Telekom (press release of Preussag, July 12, 2002).

32 To sell phantom stocks after the vesting period no absolute or relative performance target has to be met, which is unusual for German compensation practice.

33 Preussag Annual Report 2002, pp. 207-208, Preussag Annual report 2003, pp. 206-207.

34 In fiscal year 2004 Preussag disclosed individual salaries for the first time. Michael Frenzel earned $€ 3,220,000$ in 2004 (Preussag Annual Report 2004, pp. 196-197). 
Our compensation analysis also suggests that contracts did not align the interests of management with those of shareholders. Management board members together held 1,690 shares worth $€ 27,000$ and representing about $0.001 \%$ of Preussag's capital in $2002{ }^{35}$ So compensation on the whole had practically no relationship to performance, in line with the practice of most German companies until the late 1990s. ${ }^{36}$ The question of how much performance sensitivity would constitute a sufficiently high-powered compensation contract is open to debate. Jensen and Murphy (1990) establish that US CEOs receive an additional $\$ 3.25$ for every $\$ 1,000$ of shareholder value they create and regard this value as too low. Murphy (1999) points out that the picture had changed during the 1990s when performance sensitivity increased. Schwalbach and Graßhoff (1997) indicate that the situation is generally worse in Germany than in the United States. Preussag's pay for performance sensitivity was just 1 cent for every thousand euros of shareholder value created, a number that falls short of Jensen and Murphy's number and that appears too low to provide effective incentive alignment.

The case of Preussag therefore corroborates the findings of Mehran, Nogler, and Schwartz (1998) who document a relationship between voluntary liquidation decisions and CEO incentives. An example of a case where good alignment of incentives created shareholder value through a partial liquidation is General Dynamics (see Dial and Murphy, 1995). However, Mehran, Nogler, and Schwartz (1998) also point to the importance of complementary governance structures, particularly the board of directors, to induce voluntary liquidations, a subject to which we turn next.

\subsection{Ownership and Control: The Role of WestLB}

A change in strategy could have been forced upon management by its large shareholders or its supervisory board. Typically, this would take the form of replacing management with one that is more likely to execute a strategy that is in the interest of shareholders. However, Frenzel, who assumed the position of CEO on January 1, 1994 still held this position eleven years later, after initially failing to restructure the core business, and then failing equally at guiding Preussag to a more profitable future by entering a new industry. Generally, the rate of CEO turnover for German companies is high (see Kaplan, 1994), and this continuity is therefore surprising. This outcome can be easily understood, however, if we look at the distribution of votes and the composition of the supervisory board.

[Insert Table 9 about here]

35 Preussag Annual Report 2002 pp. 208-209. At the end of 2003 the shareholdings of the management board dropped to 784 shares worth $€ 13,000$ or about $0.0005 \%$ (Preussag Annual Report 2003, p. 208). The number of shares stayed constant in 2004 (Preussag Annual Report 2004, p. 198). 
Voting power. WestLB has been the only major blockholder at Preussag since 1969 (see Section 2 and Figure 1A). Table 9 displays data on WestLB's voting power in nine of the ten annual general meetings of Preussag during the period under consideration. On average, $57 \%$ of the capital was represented and WestLB had $59.2 \%$ of the votes represented by virtue of its direct shareholdings, sufficient to command a majority at four of these meetings. At another four meetings WestLB commanded the majority jointly with Niedersachsen Holding (see Figure 1A). At the one remaining meeting on March 31, 1999 WestLB commanded $49.3 \%$ of the votes, just short of a majority. We therefore conclude that WestLB dominated Preussag through its voting power.

Supervisory board. ${ }^{37}$ The supervisory board of Preussag is subject to the German codetermination act, so half of its twenty members are representatives of workers and the other half represent shareholders. Of the latter, two are representatives of WestLB as its major shareholder and Neuber, CEO of WestLB, is also the chairman of Preussag's supervisory board throughout the entire period. ${ }^{38}$ Figure 4 demonstrates that WestLB strengthened its influence through board interlocks. At any time at least two of Preussag's supervisory board members were members of the management board in other firms in which Neuber was also chairman of the supervisory board (RWE) or at least held supervisory board memberships (like Deutsche Bahn or ThyssenKrupp). The supervisory board also included representatives of other German banks and corporations, an independent (Frantz Vranitzky, former social-democratic chancellor of Austria) and an organization representing small shareholders (DSW). Only this last supervisory board member should have had a clear interest in furthering shareholder value, but we are not aware that he ever raised his voice. On December 31, 2002, when the shareholdings of the supervisory board were disclosed for the first time, all board members together held 0.002\% of Preussag's shares (Preussag, Annual Report 2002, pp. 208-209). Economists have always viewed board interlocks with skepticism (the classic reference is Dooley, 1969). Loderer and Peyer (2002) and Dittmann, Maug, and Schneider (2005) relate interlocks to performance. Loderer and Peyer (2002) show for a sample of Swiss firms that the proportion of directors who are also directors on the board of a bank has a negative impact on Tobin's q. Dittmann, Maug, and Schneider (2005) show that bank representation on the board causes lower valuations of German companies.

[Insert Figure 4 about here]

\footnotetext{
36 This calculation of performance sensitivity does not include the phantom stock scheme that was introduced in 2001 (Preussag's Annual Report, 2002), as we do not know the parameters of this scheme.

37 All the information about supervisory board meetings and committees are taken from the annual reports of Preussag from 1994 to 2004 (Bericht des Aufsichtsratsvorsitzenden).

38 Friedel Neuber unexpectedly died at the age of 69 on October, 23, 2004.
} 
We conclude that WestLB's voting power was matched by the control it exercised over Preussag's supervisory board. We therefore need to understand why WestLB was unwilling to use its hold on Preussag in order to push for a more shareholder-friendly strategy and why, in particular, it failed to prevent the catastrophic acquisition of Thomson Travel. WestLB itself is state-owned and its management is accountable only to the political representatives of North Rhine Westphalia, Germany's largest and most populous state. The governance structure of WestLB itself does not impress any particular profit motive or incentive for value maximization on its management. To the contrary, the bank serves a distinct political purpose and repeatedly used its financial muscle to prevent decisions that would increase shareholder value but conflict with other, politically defined interests. Examples include the prevention of layoffs at financially distressed firms or of relocations of headquarters or production facilities into another state. ${ }^{39}$ Beyond its politically defined objectives WestLB's management seems to enjoy considerable freedom in shaping its policies.

When Preussag entered tourism, WestLB already had a number of large, if not controlling stakes in other tourism companies (see Figure 1A). Preussag's engagement in tourism opened the opportunity for WestLB to divest itself of its tourism assets. Preussag bought WestLB's TUI-stakes and 50.1\% of its Thomas Cook block. Preussag also bought WestLB's 22\% stake in the First chain of travel agencies. Hence, it is at least plausible that WestLB found Preussag to be a willing partner to divest themselves of their tourism holdings. It is therefore natural to suppose that Preussag was merely a victim of a policy forced upon it by its large shareholder. However, in the transactions where Preussag bought assets from WestLB, notably in the case of Thomas Cook, Preussag's stock gained and these gains are economically and sometimes also statistically significant (see Section 4.2). We therefore conclude that WestLB sold its assets to Preussag at a discount to their intrinsic value, which is clearly inconsistent with WestLB abusing its power over Preussag. A more plausible interpretation is that Preussag continued a strategy initially formulated and pursued by Neuber and WestLB. When WestLB collected its tourism stakes in the period 1989 - 1997, the press speculated repeatedly about Neuber's overall strategy. ${ }^{40}$ Press speculation just days before the announcement of the Hapag Lloyd takeover (Die Zeit, June 6, 1997 p. 17) discussed the different possibilities available to WestLB: either to divest its tourism holdings by merging them into a new, independent company, or by merging them

39 Examples of such interventions include Horten AG and Geresheimer Glas (Handelsblatt, December 3, 1990 p. 21), LTU (Handelsblatt, December 24, 2001, p. 12) and Babcock (Handelsblatt, January 17, 2003, p. 10).

40 Examples include Handelsblatt, June 29, 1990. Handelsblatt, June 5, 1992 p. 21, Die Zeit, January 6, 1995 and Handelsblatt February 21, 1995. The last article argues that Neuber plans an IPO of WestLB's tourism holdings in the medium term. 
with those of Preussag. It therefore appears that Frenzel completed a former project of Neuber, but without creating tangible benefits for either Preussag or WestLB.

In the final conclusion we therefore caution against the notion that large controlling shareholders are always a blessing as they help to overcome the separation of ownership and control. The literature on large shareholder monitoring typically assumes that large blockholders have a strong interest in maximizing shareholder value and ignores the additional agency conflicts if these large shareholders are companies or institutions. ${ }^{41}$ In the case of Preussag, however, the largest shareholder is an intermediary whose management has ambitions of its own. Our findings are more in line with the view of Franks and Mayer (2001) that the gains from block trades in Germany are not shared with minority shareholders: they are mainly about private benefits from control. ${ }^{42}$

Our findings also lend some support to the more general view that poor governance arises almost inevitably from combinations of public with private governance as it results in incompatible supervisory mechanisms and in a lack of accountability. Aktas, de Bodt, and Liagre (2003) summarize their reading of the literature on state-owned enterprises and privatizations in the same way, arguing that the government protects the interests of employees and other constituencies more than shareholders and that managers are hardly ever held accountable. ${ }^{43}$ We view the state ownership of WestLB as a contributing factor rather than as a prime cause because the agency problem within WestLB discussed above would exist even for a privately owned bank.

\subsection{Conflicts of Interest}

We conclude this section with a discussion of conflicts of interest in Preussag's corporate governance structure. We show that these are obvious and significant but contribute little to the explanation of Preussag's underperformance.

Political affiliations. Both Neuber and Frenzel were members of the social democratic party (SPD), Germany’s labor party. Relationships within this party seem to have played a

41 This literature is devoted to the role of large shareholders in helping shareholders to overcome the freerider problem when they need to take action against management. It dates back at least to Shleifer and Vishny (1986). Contributions include Admati, Pfleiderer, and Zechner (1994), Bolton and von Thadden (1998), Kahn and Winton (1998), Maug (1998), who all focus exclusively on shareholders' collective action problem.

42 See also Dyck and Zingales (2004) for an international comparison of private benefits of control measured from block trade data.

43 See Megginson and Netter (2001) for a survey of the empirical literature on privatizations, especially their table 1 (p. 333) that summarizes 10 empirical studies, 9 of which find underperformance of state-owned enterprises compared to private enterprises. In a study of 50 international airlines, Backx, Carney, and Gedajlovic (2002) also investigate mixed public and private ownership, which is also the case of Preussag. They find that mixed ownership companies underperform privately owned companies, but not as much as fully state-owned enterprises. 
particular role in the sale of Preussag's steel business to a holding controlled by the state of Lower Saxony under its then prime minister Gerhard Schröder. According to one magazine report, Schröder was surprised to learn so late of Frenzel's and Neuber's plans to sell Preussag's steel business to an Austrian company. ${ }^{44}$ Preussag initially negotiated with the Austrian group Voest-Alpine, but Gerhard Schröder, then fighting for re-election as prime minister of Lower Saxony, could not afford to confront the unions and Preussag steelworkers and therefore agreed to purchase the stakes from Preussag in order to buy time for an IPO. Preussag management board member Wolfgang Schultze was a representative of the SPD in the Lower Saxonian legislature and Bodo Hombach, CEO of Preussag's steel trading unit became chief of staff of chancellor Schröder's office in the fall of 1998. With Neuber and Frenzel this includes five members of this party on all sides of the transaction, which ousted Austrian Voest Alpine from the negotiations. While Preussag asserted that the offers by the state of Lower Saxony and Voest Alpine where of “equivalent value," the Voest Alpine offer was structured differently, including a 20\% stake in a joint venture with Preussag, and valued by some to be higher by about $€ 100$ million. ${ }^{45}$ It is conceivable that party affiliations also played a role when Preussag wanted to take over the $25 \%$ stake of TUI held by Deutsche Bahn (DB), Germany's state-owned railway company. They could not agree with DB on a price under the then conservative government. When Schröder became Chancellor of Germany in September 1998, Preussag's luck turned: negotiations went more smoothly and Preussag acquired the DB-stake in April 1999. ${ }^{46}$

Lack of arms-length bargaining. Our event-study analysis suggests that Preussag overpaid for Hapag-Lloyd, as their share price dropped when the final sales price was announced (see Table 3). Here two blockholders, owning 10\% of Hapag-Lloyd's shares each, were Dresdner Bank and Deutsche Bank (see Figure 1A). Both were also represented on Preussag's supervisory board at the same time (see Figure 4), so that from this point of view there was a conflict of interest as these supervisory board members represented buyer interests and seller interests at the same time.

The strongest conflict of interest arose when Preussag sold its plant construction and shipbuilding operations to Babcock Borsig AG. This time the conflict was resolved in Preussag's favor. WestLB was the largest shareholder of Babcock with only a $10 \%$ stake, and Neuber chaired its supervisory board as he did Preussag's. In addition, Preussag management board member Klaus Linnebach, responsible for plant construction and shipbuilding, was a member of Babcock's supervisory board, effectively putting the same

\footnotetext{
44 Der Spiegel, January 1, 1998, pp. 24-25.

45 See Handelsblatt, February 5, 1998, p. 13.

46 See Handelsblatt, May 15, 1998 p. 15 and Tagesspiegel, April 6, 1999 p. 21.
} 
individuals on both sides of the negotiation table, and presenting Preussag with an excellent opportunity to divest itself of its loss-making plant construction and shipbuilding arm. Minority shareholders of Babcock protested in vain, arguing that the transaction did not fit Babcock's strategy to focus on power plants. ${ }^{47}$ When the details of the transaction where disclosed on March 15, 1999, Preussag gained 7.2\% and Babcock's share lost 5\% over the $(0,1)$ window, although we need to take into account simultaneous disclosures of financial statements and planned issues of new securities (see also Table 3). Hence, this transaction supports our general conclusion that sell-offs generated value for Preussag, but this time it took the form of a redistribution at the expense of Babcock shareholders. Babcock filed for bankruptcy on July 5, 2002 and the state persecution service (equivalent to the district attorney in the US) took up investigations against Neuber, Frenzel and others because of alleged violations of German securities laws in this context. ${ }^{48}$

All of these cases are evidence for poor corporate governance, and they certainly resulted in poor decisions. However, none of them can account for the massive value destruction at Preussag and the particular strategy followed by Preussag's management. Conflicts of interest were blatant and may have caused a loss of value in some cases (Preussag steel, Hapag Lloyd), but in other instances (notably Babcock) they benefited Preussag.

\section{Reaction by Preussag's management}

We did not receive any support from Preussag in writing this study. We therefore rely exclusively on publicly available information. In April 2005, “Capital,” a German business magazine, picked up our story and confronted Preussag's CEO Michael Frenzel during an interview with some of the results from a previous version of this paper (Capital, April 28, 2005, pp. 54-55). Frenzel's arguments are revealing. He argued that our calculation according to which Preussag destroyed several billions (see Section 4.4) is "unfair, because it ignores completely that the TUI management succeeded in building Europe's largest tourism company,” thereby reemphasizing his focus on size. ${ }^{49}$

Next, Frenzel argued that the TUI-management had "created high-quality tourism jobs in Germany" and suggested that the liquidation of Preussag would have destroyed 50,000 jobs. This argument not only defies economic logic (the jobs in tourism companies would exist quite independently of whether Preussag acquired these companies or not) but also neglects that tourism employment at Preussag fell by more than 10\% between 2002 and 2004.

\footnotetext{
47 Handelsblatt, March 19, 1999, p. 14.

48 Handelsblatt, January 14, 2003, p. 1.

49 All translations from the German interview are ours.
} 
Frenzel also expressed the view that Preussag's stock was underpriced and did not reflect the company's true earning potential. When the interviewer confronted him with the result that the future profitability of Preussag was not priced into its stock, but seemed to be well anticipated in increased managerial salaries, he retorted that compensation was about average for a DAX-30-corporation. This is correct, and restates why size is important from the point of view of management, as we suspected. Still, the argument does not recognize that Preussag was among the smallest companies in the index and almost dropped from the index when its value declined in 2004.

Last, the interviewer asked Frenzel why Preussag's management would not invest in their own stock if they considered it to be underpriced (they held 784 shares at the end of 2004). The response was that "buying [shares] is not the problem. The difficulties begin, when managers sell shares. Then there is an automatic presumption of insider trading based on the assumption that managers have additional information.” Hence, managers did not want to buy shares because they would not be able to sell them again. Clearly, the notion of holding shares for the long term was not considered.

\section{Conclusion}

In this paper we analyze the history of Preussag, later renamed TUI, over the decade from 1994 to 2004, where they rebuilt an originally diversified industrial conglomerate into Europe's largest tourism company. We collect data on 125 announcements relating to 93 transactions and 292 news events during this period and analyze the sometimes puzzling history of Preussag's stock. We categorize events in order to disentangle the value impact of different parts of Preussag's strategy and test competing hypotheses for the sources of value creation and value destruction.

We find that Preussag benefited from its divestitures, whereas its engagement in tourism destroyed value. The underperformance of its stock is a direct consequence of its business strategy and cannot be attributed to exogenous shocks like the events of September 11, 2001. In the tourism industry size seems to matter little for profitability as economies of scale and gains from market power are limited. We conclude that Preussag's management sought size for its own benefit. Our analysis of corporate governance at Preussag yielded three insights that are likely to have contributed to Preussag's underperformance:

- Management compensation increased by more than $200 \%$ over the decade considered in this study. At the same time, compensation was practically unrelated to firm performance.

- Personal networks generated private benefits through additional board seats and created a governance structure where accountability was easily lost. 
- The agency problem within the largest shareholder made it not only a poor monitor but in all likelihood even a motor of the tourism strategy. Hence, the largest shareholder helped creating benefits from control rather than constraining them.

Curiously, none of the watchdogs felt particularly alarmed by the ongoing destruction of shareholder value. Preussag's stock outperformed the market during the period when they entered tourism, and analysts and the press misread this as a good signal about its decision to focus on tourism. Here our analysis becomes valuable as it shows that aggregate performance is misleading. We disentangle the impact of divestitures from the investments in tourism and show that the former created the value that camouflaged the losses from the latter. We are therefore skeptical about the role of independent analysts, some of whom did not only fail to inform the market but also failed to understand market signals as investors started to abandon the stock.

The misguided management policies at Preussag bring out an important point of the "free cash flow" theory: The problem is not just high operating cash flows, but managerial discretion over large amounts of liquid resources, independently of their source. ${ }^{50} \mathrm{At}$ Preussag, divestitures created additional liquidity - and they appear to have only been undertaken to provide this liquidity! - without any corresponding incentives for management to use this liquidity efficiently or any check against management's pet project to be the dominant tourism company in Europe.

50 The free cash flow theory goes back to Jensen (1986), (1993). DeAngelo, DeAngelo, and Wruck (2002) make a point related to ours in their analysis of managerial discretion created by liquid working capital at L. A. Gear. Lang, Poulsen, and Stulz (1995) show that the stock market discounts companies who retain the proceeds from asset sales. Allen and McConnell (1998) make a similar point on equity carve-outs. 


\section{$8 \quad$ References}

Admati, Anat R.; Paul Pfleiderer, and Josef Zechner, 1994, Large Shareholder Activism, Risk Sharing, and Financial Market Equilibrium, Journal of Political Economy 102, no. 6 (December), pp. 1097-1130

Aktas, Nihat; Eric de Bodt, and Laurent Liagre, 2003, The EADS Take-Off: An Investigation Through Stock Markets Reactions, Mimeo, Louvain-La-Neuve, (November)

Allen, Jeffrey W., and John J. McConnell, 1998, Equity Carve-Outs and Managerial Discretion, Journal of Finance 53, no. 1 (February), pp. 163-186

Backx, Mattijs, Michael Carney, and Eric Gedajlovic, 2002, Public, private and mixed ownership and the performance of international airlines, Journal of Air Transport Management 8, pp. 213-220

Baumol, William, 1959, Business Behavior, Value and Growth, New York (Macmillan Publishing Co.)

Besanko, David; David Dranove, and Mark Shanley, 2000, Economics of Strategy, New York et. al. (John Wiley \& Sons, Inc.)

Binder, John J., 1985, On the Use of the Multivariate Regression Model in Event Studies, Journal of Accounting Research 23, pp. 370-383

Bittlingmayer, George, and Thomas W. Hazlett, 2000, DOS Kapital: Has antitrust action against Microsoft created value in the computer industry? Journal of Financial Economics 55, 329-359

Bolton, Patrick, and Ernst-Ludwig von Thadden, 1998, The Ownership Structure of Firms: the Liquidity/Control Trade-Off, Journal of Finance 53, no. 1 (February)

Brown, Stephen, and Jerold B. Warner, 1985, Using Daily Stock Returns: The Case of Event Studies, Journal of Financial Economics 14, pp. 3-31

DeAngelo, Harry; Linda DeAngelo, and Karen H. Wruck, 2002, Asset Liquidity, Debt Covenants, and Managerial Discretion in Financial Distress: The Collapse of L. A. Gear, Journal of Financial Economics 64, pp. 3-34

Dial, Jay, and Kevin J. Murphy, 1995, Incentives, Downsizing, and Value Creation at General Dynamics, Journal of Financial Economics 37, pp. 261-314

Dittmann, Ingolf; Ernst Maug, and Christoph Schneider, 2005, Bankers and the Performance of German Firms, Working Paper, Erasmus University Rotterdam

Dooley, Peter C., 1969, The Interlocking Directorate, American Economic Review, pp. 314-323

Dyck, I. J. Alexander, and Luigi Zingales, 2004, Private Benefits of Control: An International Comparison, Journal of Finance 59, pp. 537-600

Eckbo, B. Espen, 1992, Mergers and the Value of Antitrust Deterrence, Journal of Finance 47, no. 3 (July), pp. 1005-1029

Fama, Eugene F., 1980, Agency Problems and the Theory of the Firm, Journal of Political Economy 88, no. 2 (April), pp. 288-307

Franks, Julian, and Colin Mayer, 2001, Ownership and Control of German Corporations, Review of Financial Studies 14, no. 4 (Winter), pp. 943-977

Fuller, K.; Jeff Netter, and M. Stegemoller, 2002, What Do Returns to Acquiring Firms Tell Us? Evidence From Firms That Make Many Acquisitions, Journal of Finance 57, no. 4 (August), pp. 1763-1793

Graham, John R.; Michael Lemmon, and Jack Wolf, 2002, Does Corporate Diversification Destroy Value?, Journal of Finance 57, pp. 695-720

Jensen, Michael C., 1986, Agency Costs of Free Cash Flow, Corporate Finance, and Takeovers, American Economic Review 76, no. 2 (May), pp. 323-329

1993, Presidential Address: The Modern Industrial Revolution, Exit, and the Failure of Internal Control Systems, Journal of Finance 48, no. 3 (July), pp. 831-880 
Jensen, Michael C., and Kevin J. Murphy, 1990, Performance Pay and Top-Management Incentives, Journal of Political Economy 98, no. 2 (April), pp. 225-264

Kahn, Charles, and Andrew Winton, 1998, Ownership Structure, Speculation, and Shareholder Intervention, Journal of Finance 53, no. 1 (February), pp. 99-129

Kaplan, Steven N., 1994, Top Executives, Turnover, and Firm Performance in Germany, Journal of Law, Economics, and Organization 10, no. 1, pp. 142-159

Khorana, Ajay, and Marc Zenner, 1998, Executive Compensation of Large Acquirers in the 1980s, Journal of Corporate Finance 4, pp. 209-240

Lang, Larry; Annette Poulsen, and Rene Stulz, 1995, Asset Sales, Firm Performance, and the Agency Costs of Managerial Discretion, Journal of Financial Economics 37, no. 1 (January), pp. 337

Lins, Karl, and Henri Servaes, 1999, International Evidence on the Value of Corporate Diversification, Journal of Finance 54, no. 6 (December), pp. 2215-2239

Loderer, Claudio, and Peyer Urs, 2002, Board Overlap, Seat Accumulation and Share Prices, European Financial Management

Martin, John D., and Akin Sayrak, 2003, Corporate Diversification and Shareholder Value, Journal of Corporate Finance 9, pp. 37-57

Maug, Ernst, 1998, Large Shareholders As Monitors: Is There a Trade-Off Between Liquidity and Control? Journal of Finance 53, no. 1 (February), pp. 65-98

Megginson, W., and Jeffrey Netter, 2001, From State to Market: a Survey of Empirical Studies on Privatization, Journal of Economic Literature 2, pp. 321-389

Mehran, H.; G. Nogler, and K. Schwartz, 1998, CEO Incentive Plans and Corporate Liquidation Policy, Journal of Financial Economics 50, pp. 319-149

Mueller, Dennis, 1985, Mergers and Market Share, Review of Economics and Statistics 67, no. 2 (May), pp. 259-267

Murphy, Kevin J., 1999, Executive Compensation, in: Ashenfelter, O., and D. Cards (editors): Handbook of Labor Economics, 3, Amsterdam, pp. 2485-563

Parrino, Robert, 1997, Spin-Offs and Wealth Transfers: The Marriott Case, Journal of Financial Economics 43, pp. 241-247

Raj, Mahendra, and Michael Forsyth, 2003, Hubris Amongst U.K. Bidders and Losses to Shareholders, International Journal of Business 8, no. 1

Ravenscraft, David J., and F. M. Scherer, 1987, Mergers, Selloffs and Economic Efficiency, Washington, D. C. (The Brookings Institute)

Roll, Richard, 1986, The Hubris Hypothesis of Corporate Takeovers, Journal of Business 59, no. 2 (April), pp. 197-216

Schwalbach, Joachim, 1999, Entwicklung der Managementvergütung, Forschungsbericht 99-2, School of Business and Economics, Humboldt Universität zu Berlin

Schwalbach, Joachim, and Graßhoff Ulrike, 1997, Managervergütung und Unternehmenserfolg, Zeitschrift für Betriebswirtschaft 67, no. 2, pp. 203-217

Shleifer, Andrei, and Robert W. Vishny, 1986, Large Shareholders and Corporate Control, Journal of Political Economy 94, no. 3 (June), pp. 176-216

Villalonga, Belen, 2004, Does Diversification Cause the 'Diversification Discount'?, Financial Management 33, no. 2 (Summer) 


\section{Table 1: Preussag's sales by business units}

This table displays the sales of Preussag's business units, including sales between units. In 2001, Preussag changed its end of fiscal year from September 30 to December 31. The table does not report sales for the shortened fiscal year that consisted only of the last quarter of 2000. The Herfindahl index reflects the degree of diversification of the conglomerate. It is equal to the sum over all divisions of their squared percentages of sales. All numbers before conversion to the euro in 1999 are reported in euros using the official conversion rate of $1.95583 \mathrm{DM} / €$.

Panel 1A: Preussag's sales from 1992/93 to 1997/98

\begin{tabular}{|c|c|c|c|c|c|c|c|c|c|c|c|c|}
\hline & \multicolumn{2}{|c|}{ 1992/93 } & \multicolumn{2}{|c|}{ 1993/94 } & \multicolumn{2}{|c|}{ 1994/95 } & \multicolumn{2}{|c|}{ 1995/96 } & \multicolumn{2}{|c|}{ 1996/97 } & \multicolumn{2}{|c|}{ 1997/98 } \\
\hline & Mill. $€$ & $\%$ & Mill. $€$ & $\%$ & Mill. $€$ & $\%$ & Mill. $€$ & $\%$ & Mill. $€$ & $\%$ & Mill. $€$ & $\%$ \\
\hline Tourism & - & - & - & - & - & - & - & - & - & - & 5,530 & $27.9 \%$ \\
\hline Steel production & 1,409 & $10.4 \%$ & 1,683 & $12.4 \%$ & 1,876 & $12.4 \%$ & 1,615 & $11.2 \%$ & 1,787 & $11.5 \%$ & - & - \\
\hline Non-ferrous metal production & 652 & $4.8 \%$ & 612 & $4.5 \%$ & 691 & $4.6 \%$ & 723 & $5.0 \%$ & 370 & $2.4 \%$ & - & - \\
\hline Oil and gas production & 524 & $3.9 \%$ & 501 & $3.7 \%$ & 520 & $3.4 \%$ & 577 & $4.0 \%$ & 702 & $4.5 \%$ & 905 & $4.6 \%$ \\
\hline Mining activities & 953 & $7.0 \%$ & 718 & $5.3 \%$ & 742 & $4.9 \%$ & 678 & $4.7 \%$ & 556 & $3.6 \%$ & 607 & $3.1 \%$ \\
\hline Logistics & 479 & $3.5 \%$ & 479 & $3.5 \%$ & 954 & $6.3 \%$ & 1,025 & $7.1 \%$ & 1,060 & $6.8 \%$ & 3,242 & $16.4 \%$ \\
\hline Shipbuilding & 822 & $6.1 \%$ & 688 & $5.1 \%$ & 576 & $3.8 \%$ & 911 & $6.3 \%$ & 610 & $3.9 \%$ & 572 & $2.9 \%$ \\
\hline Railcar manufacturing & 220 & $1.6 \%$ & - & - & - & - & - & - & - & - & - & - \\
\hline Plant construction & 1,512 & $11.2 \%$ & 1,475 & $10.9 \%$ & 1,706 & $11.3 \%$ & 1,675 & $11.6 \%$ & 2,121 & $13.6 \%$ & 1,663 & $8.4 \%$ \\
\hline Information technology & 591 & $4.4 \%$ & 310 & $2.3 \%$ & - & - & - & - & - & - & - & - \\
\hline Building engineering & 950 & $7.0 \%$ & 1,036 & $7.6 \%$ & 1,137 & $7.5 \%$ & 1,321 & $9.1 \%$ & 1,840 & $11.8 \%$ & 1,909 & $9.6 \%$ \\
\hline Other/Consolidation & 242 & $1.8 \%$ & 257 & $1.9 \%$ & 253 & $1.7 \%$ & 294 & $2.0 \%$ & 289 & $1.9 \%$ & 282 & $1.4 \%$ \\
\hline Total & 13,518 & $100.0 \%$ & 13,543 & $100.0 \%$ & 15,133 & $100.0 \%$ & 14,483 & $100.0 \%$ & 15,569 & $100.0 \%$ & 19,791 & $100.0 \%$ \\
\hline Earnings before Taxes & 177 & $1.3 \%$ & 258 & $1.9 \%$ & 317 & $2.1 \%$ & 239 & $1.7 \%$ & 360 & $2.3 \%$ & 521 & $2.6 \%$ \\
\hline Herfindahl index & & $18.1 \%$ & & $21.6 \%$ & & $23.4 \%$ & & $19.8 \%$ & & $21.2 \%$ & & $19.1 \%$ \\
\hline
\end{tabular}


Panel 1B: Preussag's sales from 1998/99 to 2004

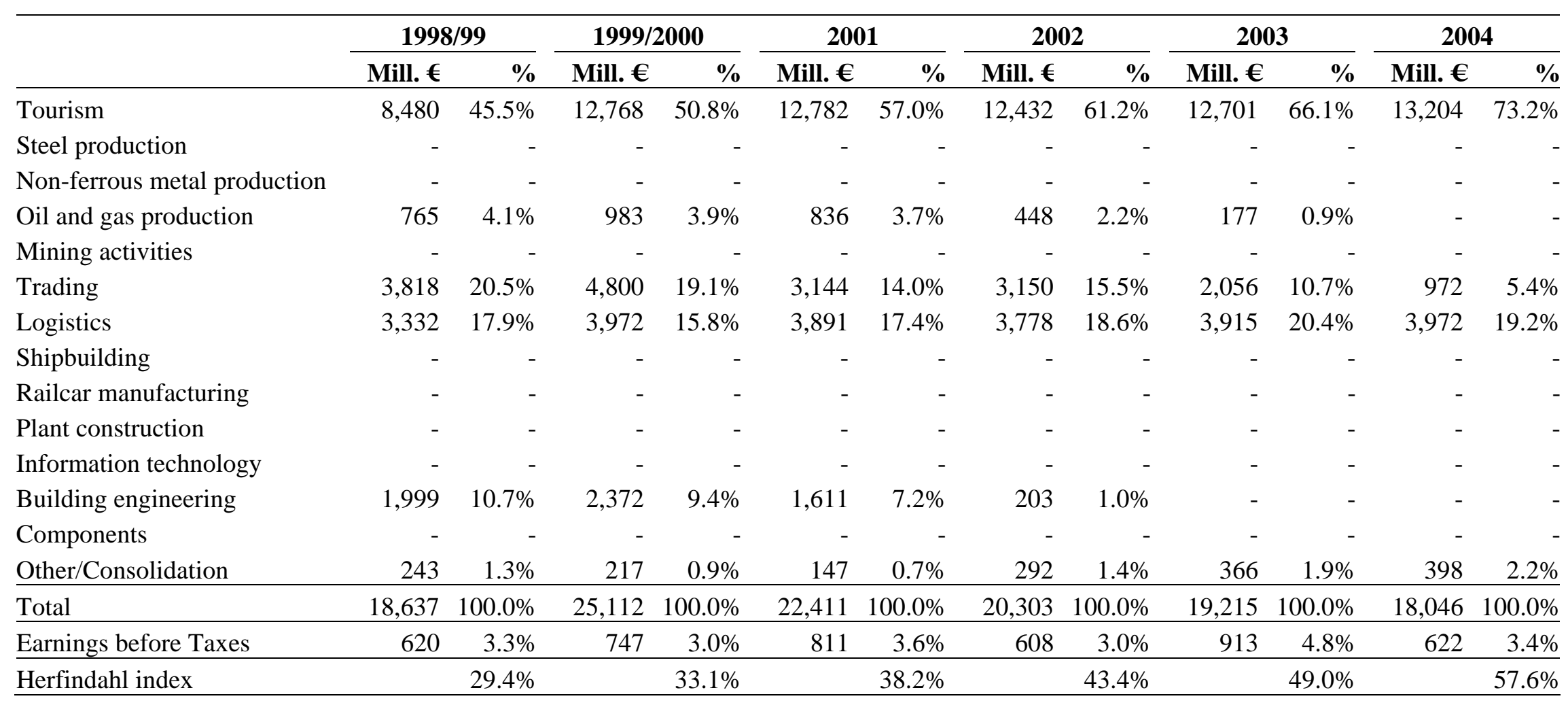




\section{Table 2: Preussag's abnormal returns in Phase 1: Consolidate core businesses (1994-1997)}

This table presents the results of eight regressions of Preussag's daily abnormal log returns over phase 1 from January 1, 1994 to June 10, 1997 on an intercept and three dummy variables: acquisitions, sell-offs, and news. The dummy variables are set equal to one on every day of the event windows around the events they indicate. The table reports the estimated regression coefficients multiplied by the number of days the respective dummy variable is equal to one. Unexplained return is the estimated intercept multiplied by the number of observations in the regression. ${ }^{\circ}, *$, **, *** marks significance at the $15 \%, 10 \%, 5 \%$, and $1 \%$ significance level, respectively. Results are displayed for four different event windows $(-x, y)$ from $x$ days before to $y$ days after the event. Panel A presents regression results for abnormal returns calculated relative to the Frankfurt market portfolio CDAX. Panel B contains similar results when abnormal returns are calculated relative to our weighted industry benchmark.

Panel A: Abnormal returns relative to the market index (CDAX)

\begin{tabular}{lccccc}
\hline \multirow{2}{*}{ Event group } & \multirow{2}{*}{$\begin{array}{c}\text { Number } \\
\text { of events }\end{array}$} & $\mathbf{5}$ Event window \\
\cline { 3 - 6 } & 12 & $0.13 \%$ & $-1.58 \%$ & $-2.72 \%$ & $-4.58 \%$ \\
\hline Acquisitions & 15 & $3.97 \%$ & $-0.15 \%$ & $6.92 \%$ & $2.62 \%$ \\
Sell-offs & 67 & $-24.35 \%^{* *}$ & $-25.99 \%^{*}$ & $-35.62 \% \%^{* *}$ & $-43.36 \%^{* * *}$ \\
News & N/A & $3.13 \%$ & $10.60 \%$ & $14.30 \%$ & $28.21 \%$ \\
\hline Unexplained returns & N/A & $-17.11 \%$ & $-17.11 \%$ & $-17.11 \%$ & $-17.11 \%$ \\
\hline Total return & & &
\end{tabular}

Panel B: Abnormal returns relative to weighted industry benchmark

\begin{tabular}{lccccc}
\hline \multirow{2}{*}{ Event group } & \multirow{2}{*}{$\begin{array}{c}\text { Number } \\
\text { of events }\end{array}$} & \multicolumn{5}{c}{ Event window } \\
\cline { 3 - 6 } & 12 & $-1.82 \%$ & $-1.59 \%$ & $-5.73 \%$ & $-5.72 \%$ \\
\hline Acquisitions & 15 & $11.53 \%^{*}$ & $0.26 \%$ & $10.79 \%$ & $-0.81 \%$ \\
Sell-offs & 67 & $-21.76 \%^{\circ}$ & $-26.87 \%^{\circ}$ & $-30.78 \%^{*}$ & $-40.09 \% * *$ \\
News & N/A & $-10.71 \%$ & $5.44 \%$ & $2.96 \%$ & $23.86 \%$ \\
\hline Unexplained returns & N/A & $-22.76 \%$ & $-22.76 \%$ & $-22.76 \%$ & $-22.76 \%$ \\
\hline Total return & & & &
\end{tabular}


Table 3: Individual cumulative abnormal returns in Phase 2: Enter Tourism (1997-2001)

This table displays the cumulative abnormal log returns over four different event windows $(-x, y)$ from $x$ days before to $y$ days after the event.

\begin{tabular}{|c|c|c|c|c|c|}
\hline \multirow{2}{*}{$\begin{array}{l}\text { Date of } \\
\text { Ann. }\end{array}$} & \multirow{2}{*}{ Description of event } & \multicolumn{4}{|c|}{ Cumulated Abnormal Returns } \\
\hline & & $(0,1)$ & $(-1,1)$ & $(0,2)$ & $(-1,2)$ \\
\hline 11 Jun 97 & $\begin{array}{l}\text { Preussag announces the plan to acquire the tourism and logistics company Hapag-Lloyd. } \\
\text { Sales: } € 2.3 \mathrm{bn} \text {. }\end{array}$ & $3.1 \%$ & $2.4 \%$ & $2.7 \%$ & $2.0 \%$ \\
\hline 02 Sep 97 & $\begin{array}{l}\text { Preussag announces the agreement with Hapag-Lloyd shareholders to acquire } 99.2 \% \text { of all } \\
\text { shares for } € 1.43 \mathrm{bn} \text {. }\end{array}$ & $-4.7 \% * *$ & $-6.4 \% * *$ & $-6.4 \% * *$ & $-8.1 \% * * *$ \\
\hline 12 Jan 98 & $\begin{array}{l}\text { Preussag sells } 51 \% \text { and an option for the remaining } 48.8 \% \text { of its steel production unit } \\
\text { (Preussag Stahl AG) to the state of Lower Saxony and NordLB. Price: } € 542 \mathrm{~m}\end{array}$ & $6.2 \% * * *$ & $6.0 \% * *$ & $4.5 \% *$ & $4.2 \%$ \\
\hline 02 Mar 98 & $\begin{array}{l}\text { German federal cartel office allows Preussag to acquire Hapag-Lloyd and the majority of } \\
\text { TUI. At the same time Schickedanz-Group announces to sell its } 20 \% \text { stake of TUI. After } \\
\text { WestLB and Deutsche Bahn exercise their pre-emptive rights to purchase } 7.5 \% \\
\text { respectively 5\% of TUI shares, Preussag acquires the remaining } 7.5 \% \text {. Price: } € 96 \mathrm{~m}\end{array}$ & $3.6 \%{ }^{\circ}$ & $3.3 \%$ & $4.3 \%^{\circ}$ & $4.1 \%$ \\
\hline 09 Jun 98 & $\begin{array}{l}\text { Preussag announces the acquisition of } 12.6 \% \text { of TUI from WestLB. Preussag becomes } \\
\text { majority shareholder of TUI. Price: } € 160 \mathrm{~m}\end{array}$ & $3.0 \%$ & $1.8 \%$ & $3.0 \%$ & $1.9 \%$ \\
\hline 02 Jul 98 & $\begin{array}{l}\text { Preussag reorganizes its tourism activities in a new holding (Hapag Touristik Union). } \\
\text { Sales: €5.3bn }\end{array}$ & $1.0 \%$ & $0.2 \%$ & $4.4 \% *$ & $3.6 \%$ \\
\hline 06 Jul 98 & $\begin{array}{l}\text { Reorganization of Preussag's management board. The division managers lose power. This } \\
\text { is an important step for the coming divestitures of Preussag. }\end{array}$ & $9.1 \% * * *$ & $10.6 \% * * *$ & $13.3 \% * * *$ & $14.8 \% * * *$ \\
\hline 06 Oct 98 & $\begin{array}{l}\text { WestLB and Carlson agree on a merger of Thomas Cook and the UK business of Carlson; } \\
\text { Carlson will hold } 22 \% \text { and WestLB } 78 \% \text { of the merged company. }\end{array}$ & $-6.3 \% * *$ & $-4.3 \%$ & $-3.5 \%$ & $-1.6 \%$ \\
\hline 08 Oct 98 & $\begin{array}{l}\text { Rumors about further transactions between Preussag and WestLB. Preussag confirms talks } \\
\text { with WestLB about an acquisition or cooperation with Thomas Cook. }\end{array}$ & $6.7 \% * * *$ & $4.6 \% *$ & $9.0 \% * * *$ & $7.0 \% * *$ \\
\hline 12 Nov 98 & $\begin{array}{l}\text { After an intervention of Germany's federal cartel office WestLB has to sell its stake in } \\
\text { LTU. Until the end of 2000, WestLB formally keeps } 10.2 \% \text { of LTU because of } \\
\text { international aviation laws. }\end{array}$ & $0.3 \%$ & $1.2 \%$ & $-1.6 \%$ & $-0.7 \%$ \\
\hline 02 Dec 98 & $\begin{array}{l}\text { Rumors that Preussag plans to acquire Thomas Cook and negotiates with WestLB about } \\
\text { WestLB's stake in Thomas Cook. }\end{array}$ & $0.5 \%$ & $5.4 \% * *$ & $3.6 \%$ & $8.6 \% * * *$ \\
\hline 17 Dec 98 & Preussag acquires $100 \%$ of First travel agencies (22\% from WestLB). Sales: $1.8 \mathrm{bn}$. & $3.3 \%{ }^{\circ}$ & $4.8 \% *$ & $3.5 \%$ & $5.0 \%{ }^{\circ}$ \\
\hline 23 Dec 98 & $\begin{array}{l}\text { Preussag acquires } 24.9 \% \text { and an option for further } 25.2 \% \text { of Thomas Cook from WestLB } \\
\text { for } € 146 \mathrm{~m} \text {. }\end{array}$ & $0.5 \%$ & $-1.8 \%$ & $-0.5 \%$ & $-2.8 \%$ \\
\hline
\end{tabular}




\begin{tabular}{|c|c|c|c|c|c|}
\hline \multirow{2}{*}{$\begin{array}{l}\text { Date of } \\
\text { Ann. }\end{array}$} & \multirow{2}{*}{ Description of event } & \multicolumn{4}{|c|}{ Cumulated Abnormal Returns } \\
\hline & & $(0,1)$ & $(-1,1)$ & $(0,2)$ & $(-1,2)$ \\
\hline 05 Jan 99 & $\begin{array}{l}\text { Preussag sells its complete share of 50.2\% of Deilmann-Haniel GmbH (mining and } \\
\text { engineering firm) to the Heitkamp-Group. Sales: €373m }\end{array}$ & $1.6 \%$ & $7.4 \% * * *$ & $-1.3 \%$ & $4.5 \%^{\circ}$ \\
\hline 02 Feb 99 & $\begin{array}{l}\text { Preussag announces talks about its plant construction and shipbuilding units with Babcock } \\
\text { (a German plant construction company). Sales: } € 2.1 \mathrm{bn} \text {. At the same day: publication of } \\
\text { Preussag's annual accounts and announcement of an equity rights issue. }\end{array}$ & $-4.6 \% * *$ & $1.0 \%$ & $-6.8 \% * *$ & $-1.2 \%$ \\
\hline 08 Feb 99 & $\begin{array}{l}\text { Babcock's supervisory board agrees to the acquisition of Preussag's plant construction and } \\
\text { shipbuilding business. }\end{array}$ & $4.0 \% *$ & $7.0 \% * * *$ & $-0.8 \%$ & $2.3 \%$ \\
\hline 15 Mar 99 & $\begin{array}{l}\text { Preussag and Babcock close the deal. Preussag receives } € 180 \mathrm{~m} \text { in stock and } € 142 \mathrm{~m} \text { in cash } \\
\text { for } 100 \% \text { of its plant construction and } 50 \% \text { of its shipbuilding unit. }\end{array}$ & $7.2 \% * * *$ & $4.4 \%^{\circ}$ & $4.3 \%^{\circ}$ & $1.5 \%$ \\
\hline 06 Apr 99 & $\begin{array}{l}\text { Preussag's acquires 25\% of TUI from Deutsche Bahn (German railway operator). Price: } \\
€ 320 \mathrm{~m} \text {. }\end{array}$ & $1.5 \%$ & $0.0 \%$ & $4.7 \%^{\circ}$ & $3.2 \%$ \\
\hline 17 Jun 99 & $\begin{array}{l}\text { Preussag and Kuoni (largest Swiss tourism company) announce a cooperation of their } \\
\text { tourism activities in Switzerland. Kuoni gets the option to acquire up to } 49 \% \text { of TUI } \\
\text { Suisse. Sales of TUI Suisse: } € 343 \mathrm{~m}\end{array}$ & $2.1 \%$ & $2.2 \%$ & $8.1 \% * * *$ & $8.3 \% * * *$ \\
\hline 01 Jul 99 & Preussag acquires the remaining $24.9 \%$ of TUI from WestLB. & $-2.3 \%$ & $-2.6 \%$ & $2.3 \%$ & $2.1 \%$ \\
\hline 30 Sep 99 & Preussag exercises its option to acquire another $25.2 \%$ of Thomas Cook from WestLB. & $-3.9 \%^{\circ}$ & $-6.3 \% *$ & $-2.5 \%$ & $-4.8 \%$ \\
\hline 04 Feb 00 & $\begin{array}{l}\text { Preussag announces to acquire } 75 \% \text { of Goulet Touropa (Austria's largest tourism } \\
\text { company). Sales: €330m }\end{array}$ & $-1.2 \%$ & $-1.3 \%$ & $-7.6 \% * * *$ & $-7.6 \% * * *$ \\
\hline 12 May 00 & $\begin{array}{l}\text { Rumors about a new bidder, most probably Preussag, in the takeover battle between C\&N } \\
\text { (3rd largest European tourism group) and Thomson Travel Group plc (4th largest } \\
\text { European tourism company). }\end{array}$ & $-9.1 \% * * *$ & $-10.5 \% * * *$ & $-15.8 \% * * *$ & $-17.3 \% * * *$ \\
\hline 15 May 00 & $\begin{array}{l}\text { Preussag announces the friendly takeover of the Thomson Travel Group plc. Price: } € 2.8 \mathrm{bn} \text {. } \\
\text { At the same day: publication of Preussag's interim semi-annual accounts, which were in } \\
\text { line with market expectations. }\end{array}$ & $-11.9 \% * * *$ & $-15.8 \% * * *$ & $-9.9 \% * * *$ & $-13.9 \% * * *$ \\
\hline $13 \mathrm{Jul} 00$ & Profit warning from Airtours (3rd largest European tourism company). & $-7.9 \% * * *$ & $-8.5 \% * * *$ & $-10.0 \% * * *$ & $-10.7 \% * * *$ \\
\hline 01 Aug 00 & $\begin{array}{l}\text { Preussag announces the plan to sell all 21,000 apartments of its real estate activities. Price: } \\
\text { ca. } € 500 \mathrm{~m}\end{array}$ & $6.4 \% * * *$ & $9.4 \% * * *$ & $9.9 \% * * *$ & $12.9 \% * * *$ \\
\hline 09 Oct 00 & $\begin{array}{l}\text { Preussag announces the stepwise acquisition of Nouvelles Frontières (largest French } \\
\text { tourism company). Price for the complete acquisition: } € 123 \mathrm{~m}\end{array}$ & $4.6 \% * *$ & $4.4 \%^{\circ}$ & $3.0 \%$ & $2.8 \%$ \\
\hline 05 Dec 00 & $\begin{array}{l}\text { Preussag sells its share (50.1\%) of Thomas Cook to C\&N Touristic to avoid an } \\
\text { intervention of European competition authorities against the Thomson Travel takeover. } \\
\text { Price: } € 450 \mathrm{~m}\end{array}$ & $5.0 \% * *$ & $7.0 \% * *$ & $4.9 \% *$ & $6.8 \% * *$ \\
\hline 04 Apr 01 & Preussag acquires the remaining 50\% of its Belgian tourism subsidiary TUI Belgium. & $-3.7 \% *$ & $-3.6 \%$ & $-5.2 \% * *$ & $-5.1 \% *$ \\
\hline
\end{tabular}




\section{Table 4: Preussag's abnormal returns in Phase 2: Enter Tourism (1997-2001)}

This table presents the results of eight regressions of Preussag's daily abnormal log returns over phase 2 from June 11, 1997 to September 10, 2001 on an intercept and six dummy variables: tourism acquisitions from WestLB, other tourism acquisitions, other (non-tourism) acquisitions, sell-offs, tourism news, and other news. The dummy variables are set equal to one on every day of the event windows around the events they indicate. The table reports the estimated regression coefficients multiplied by the number of days the respective dummy variable is equal to one. Unexplained return is the estimated intercept multiplied by the number of observations in the regression. ${ }^{\circ}, *, * *, * * *$ marks significance at the $15 \%, 10 \%, 5 \%$, and $1 \%$ significance level, respectively. Results are displayed for four different event windows $(-x, y)$ from $x$ days before to $y$ days after the event. Panel A presents regression results for abnormal returns calculated relative to the Frankfurt market portfolio CDAX. Panel B contains similar results when abnormal returns are calculated relative to our weighted industry benchmark.

\section{Panel A: Abnormal returns relative to the market index (CDAX)}

\begin{tabular}{lrrrrr}
\hline \multirow{2}{*}{ Event group } & Number & \multicolumn{5}{c}{ Event window } \\
\cline { 4 - 6 } of events & $\mathbf{( 0 , 1 )}$ & $\mathbf{( - 1 , 1 )}$ & $\mathbf{( 0 , 2 )}$ & $\mathbf{( - 1 , 2 )}$ \\
\hline Tourism acquisitions & & & & & \\
$\quad$ from WestLB & 6 & $10.37 \%^{\circ}$ & $9.20 \%$ & $16.27 \%^{*}$ & $15.05 \%^{\circ}$ \\
$\quad$ other & 23 & $-22.59 \%^{\circ}$ & $-37.37 \%^{* *}$ & $-34.92 \%^{* *}$ & $-52.41 \%^{* * *}$ \\
Other acquisitions & 10 & $13.44 \%^{\circ}$ & $10.00 \%^{*}$ & $13.01 \%^{\circ}$ & $10.00 \%^{*}$ \\
Sell-offs & 25 & $44.69 \%^{* * *}$ & $52.17 \%^{* * *}$ & $26.87 \%^{\circ}$ & $37.47 \%^{*}$ \\
Tourism news & 8 & $8.00 \%$ & $20.18 \%^{* *}$ & $4.24 \%$ & $16.59 \%$ \\
Other news & 80 & $16.21 \%$ & $42.58 \%$ & $18.09 \%$ & $43.85 \%$ \\
Unexplained returns & N/A & $-47.99 \%$ & $-74.63 \%$ & $-21.43 \%$ & $-48.42 \%$ \\
\hline Total return & N/A & $22.13 \%$ & $22.13 \%$ & $22.13 \%$ & $22.13 \%$ \\
\hline
\end{tabular}

Panel B: Abnormal returns relative to weighted industry benchmark

\begin{tabular}{lrcccc}
\hline \multirow{2}{*}{ Event group } & $\begin{array}{c}\text { Number } \\
\text { of events }\end{array}$ & \multicolumn{5}{c}{ Event window } \\
\cline { 5 - 7 } & & $\mathbf{( 0 , 1 )}$ & $\mathbf{( - 1 , \mathbf { 1 } )}$ & $\mathbf{( 0 , 2 )}$ & $\mathbf{( - 1 , 2 )}$ \\
\hline Tourism acquisitions & & & & & \\
$\quad$ from WestLB & 6 & $8.81 \%$ & $9.19 \%^{*}$ & $15.79 \%^{*}$ & $16.13 \%^{*}$ \\
$\quad$ other & 23 & $-17.29 \%^{*}$ & $-37.83 \%^{* *}$ & $-24.49 \%^{\circ}$ & $-47.53 \%^{* *}$ \\
Other acquisitions & 10 & $15.98 \%^{*}$ & $16.90 \%^{\circ}$ & $11.74 \%$ & $12.90 \%$ \\
Sell-offs & 25 & $37.88 \%^{* * *}$ & $48.31 \%^{* * *}$ & $14.41 \%$ & $27.44 \%$ \\
Tourism news & 8 & $2.74 \%$ & $8.42 \%^{*}$ & $0.71 \%$ & $6.57 \%$ \\
Other news & 80 & $34.08 \%$ & $49.32 \%^{\circ}$ & $36.08 \%$ & $52.25 \%^{\circ}$ \\
Unexplained returns & N/A & $-58.13 \%$ & $-70.26 \%$ & $-30.16 \%$ & $-43.68 \%$ \\
\hline Total return & N/A & $24.07 \%$ & $24.07 \%$ & $24.07 \%$ & $24.07 \%$ \\
\hline
\end{tabular}




\section{Table 5: Event study approach for Phase 2: Enter Tourism (1997-2001)}

This table displays cumulative abnormal log returns (CARs) over the event windows of several groups of events over phase 2 from June 11, 1997 to September 10, 2001. The 'number of events' is the number of days on which events of the respective event group took place. Note that this number can be lower than the corresponding number in Table 4, because days on which more than one event (from different event groups) took place are classified as 'Multiple events' here. Around these days, event windows are fitted, and abnormal returns are cumulated across these windows. ${ }^{\circ}, *, * *, * * *$ marks significance at the $15 \%, 10 \%, 5 \%$, and $1 \%$ significance level, respectively. Results are displayed for four different event windows $(-x, y)$ from $x$ days before to $y$ days after the event. Panel A presents regression results for abnormal returns calculated relative to the Frankfurt market portfolio CDAX. Panel B contains similar results when abnormal returns are calculated relative to our weighted industry benchmark. The table also shows a breakdown of the CARs of tourism acquisitions into the CARs of tourism acquisitions from WestLB and the CARs of other tourism acquisitions.

\section{Panel A: Abnormal returns relative to the market index (CDAX)}

\begin{tabular}{lrcccc}
\hline \multirow{2}{*}{ Event group } & \multirow{2}{*}{$\begin{array}{c}\text { Number } \\
\text { of events }\end{array}$} & \multicolumn{5}{c}{ Event window } \\
\cline { 3 - 6 } & 27 & $-12.61 \%$ & $-34.51 \%^{* *}$ & $-10.32 \%$ & $-25.15 \%^{\circ}$ \\
\hline Tourism acquisitions & 6 & $9.92 \%^{\circ}$ & $6.59 \%^{*}$ & $12.97 \%^{*}$ & $9.64 \%^{*}$ \\
$\quad$ from WestLB & 21 & $-22.53 \%^{* *}$ & $-41.10 \%^{* * *}$ & $-23.29 \%^{*}$ & $-34.79 \%^{* *}$ \\
other & 9 & $14.02 \%^{*}$ & $6.05 \%^{*}$ & $16.75 \%^{*}$ & $7.80 \%$ \\
Other acquisitions & 20 & $40.52 \%^{* * *}$ & $47.67 \%^{* * *}$ & $21.51 \%^{\circ}$ & $34.48 \%^{* *}$ \\
Sell-offs & 8 & $5.04 \%$ & $23.14 \%^{* * *}$ & $13.24 \%^{*}$ & $23.78 \%^{* * *}$ \\
Tourism news & 68 & $13.43 \%$ & $17.10 \%$ & $23.67 \%$ & $25.46 \%$ \\
Other news & 6 & $8.38 \%$ & $16.07 \%^{\circ}$ & $-8.12 \%$ & $1.97 \%$ \\
Multiple Events & 939 & $-46.65 \%$ & $-53.40 \%$ & $-34.60 \%$ & $-46.21 \%$ \\
\hline Days without events & 1077 & $22.13 \%$ & $22.13 \%$ & $22.13 \%$ & $22.13 \%$ \\
\hline Sum & & & & &
\end{tabular}

Panel B: Abnormal returns relative to weighted industry benchmark

\begin{tabular}{lrcccc}
\hline \multirow{2}{*}{ Event group } & Number & \multicolumn{5}{c}{ Event window } \\
\cline { 3 - 6 } & of events & $\mathbf{( 0 , 1 )}$ & $\mathbf{( - 1 , 1 )}$ & $\mathbf{( 0 , 2 )}$ & $\mathbf{( - 1 , 2 )}$ \\
\hline Tourism acquisitions & 27 & $-12.51 \%$ & $-34.37 \%^{* *}$ & $-12.62 \%$ & $-23.66 \%^{\circ}$ \\
$\quad$ from WestLB & 6 & $8.47 \%$ & $6.96 \%$ & $11.19 \%^{*}$ & $9.67 \%$ \\
$\quad$ other & 21 & $-20.98 \%^{*}$ & $-41.32 \%^{* * *}$ & $-23.81 \%^{*}$ & $-33.33 \%^{* *}$ \\
Other acquisitions & 9 & $14.64 \%^{* *}$ & $11.76 \%$ & $14.01 \%^{*}$ & $11.84 \%$ \\
Sell-offs & 20 & $35.41 \%^{* * *}$ & $45.29 \%^{* * *}$ & $12.94 \%$ & $29.74 \%^{* *}$ \\
Tourism news & 8 & $-0.16 \%$ & $10.66 \%$ & $6.77 \%$ & $10.54 \%$ \\
Other news & 68 & $24.41 \%$ & $22.76 \%$ & $25.21 \%$ & $27.07 \%$ \\
Multiple Events & 6 & $13.30 \%^{*}$ & $16.77 \%^{\circ}$ & $6.10 \%$ & $6.94 \%$ \\
Days without events & 939 & $-51.03 \%$ & $-48.80 \%$ & $-28.34 \%$ & $-38.41 \%$ \\
\hline Sum & 1077 & $24.07 \%$ & $24.07 \%$ & $24.07 \%$ & $24.07 \%$ \\
\hline
\end{tabular}




\section{Table 6: Preussag's abnormal returns in Phase 3: Consolidate Tourism (2001-2004)}

This table presents the results of eight regressions of Preussag's daily abnormal log returns over phase 3 from September 11, 2001 to December 31, 2004 on an intercept and five dummy variables: tourism acquisitions, other acquisitions, sell-offs, tourism news, and other news. The dummy variables are set equal to one on every day of the event windows around the events they indicate. The table reports the estimated regression coefficients multiplied by the number of days the respective dummy variable is equal to one. Unexplained return is the estimated intercept multiplied by the number of observations in the regression. ${ }^{\circ}, *, * *, * * *$ marks significance at the $15 \%, 10 \%, 5 \%$, and $1 \%$ significance level, respectively. Results are displayed for four different event windows $(-x, y)$ from $x$ days before to $y$ days after the event. Panel A presents regression results for abnormal returns calculated relative to the Frankfurt market portfolio CDAX. Panel B contains similar results when abnormal returns are calculated relative to our weighted industry benchmark.

Panel A: Abnormal returns relative to the market index (CDAX)

\begin{tabular}{|c|c|c|c|c|c|}
\hline \multirow{2}{*}{ Event group } & \multirow{2}{*}{$\begin{array}{l}\text { Number } \\
\text { of events }\end{array}$} & \multicolumn{4}{|c|}{ Event window } \\
\hline & & $(0,1)$ & $(-1,1)$ & $(0,2)$ & $(-1,2)$ \\
\hline Tourism acquisitions & 11 & $5.07 \%$ & $1.69 \%$ & $10.32 \%$ & $6.81 \%$ \\
\hline Other acquisitions & 1 & $1.89 \%$ & $3.61 \%$ & $1.21 \%$ & $3.07 \%$ \\
\hline Sell-offs & 22 & $-4.53 \%$ & $-14.92 \%$ & $-13.79 \%$ & $-24.12 \%$ \\
\hline Tourism news & 36 & $-20.45 \%$ & $-16.92 \%$ & $-16.38 \%$ & $-9.36 \%$ \\
\hline Other news & 101 & $22.88 \%$ & $55.36 \%$ & $30.24 \%$ & $82.95 \%^{\circ}$ \\
\hline Unexplained returns & N/A & $-54.71 \%$ & $-78.66 \%$ & $-61.44 \%$ & $-109.18 \%$ \\
\hline Total return & N/A & $-49.84 \%$ & $-49.84 \%$ & $-49.84 \%$ & $-49.84 \%$ \\
\hline
\end{tabular}

Panel B: Abnormal returns relative to weighted industry benchmark

\begin{tabular}{|c|c|c|c|c|c|}
\hline \multirow{2}{*}{ Event group } & \multirow{2}{*}{$\begin{array}{l}\text { Number } \\
\text { of events }\end{array}$} & \multicolumn{4}{|c|}{ Event window } \\
\hline & & $(0,1)$ & $(-1,1)$ & $(0,2)$ & $(-1,2)$ \\
\hline Tourism acquisitions & 11 & $-3.29 \%$ & $-5.67 \%$ & $-1.02 \%$ & $-3.47 \%$ \\
\hline Other acquisitions & 1 & $2.23 \%$ & $1.94 \%$ & $3.08 \%$ & $2.87 \%$ \\
\hline Sell-offs & 22 & $-13.28 \%$ & $-29.12 \%^{\circ}$ & $-15.59 \%$ & $-31.96 \%^{\circ}$ \\
\hline Tourism news & 36 & $-12.30 \%$ & $-7.21 \%$ & $-1.10 \%$ & $3.68 \%$ \\
\hline Other news & 101 & $36.00 \%$ & $56.54 \%$ & $38.91 \%$ & $71.10 \%$ \\
\hline Unexplained returns & N/A & $-89.96 \%$ & $-97.09 \%$ & $-104.88 \%$ & $-122.82 \%$ \\
\hline Total return & N/A & $-80.60 \%$ & $-80.60 \%$ & $-80.60 \%$ & $-80.60 \%$ \\
\hline
\end{tabular}




\section{Table 7: Return of a hypothetical liquidation of Preussag}

This table displays the evolvement and the (actual) returns of two hypothetical liquidation strategies of Preussag AG. The hypothetical strategy starts on September 30, 1997. From then on, all free cash flows including all proceeds from sell-offs are assumed to be paid out to shareholders and invested either in the tourism and transportation index or in the market index (CDAX). Index returns are actual returns and not log returns. No new acquisitions are made, and the existing debt is repaid on September 30, 1997. For each date, the value of the investment in the index of all cash flows that have previously been paid out is shown in the column 'value'. For a few smaller sell-offs, we could not obtain the proceeds, so we set the cash inflow equal to zero. For the remaining subsidiaries on December 31, 2004 we use prices obtained after December 31, 2004 or balance sheet data.

\begin{tabular}{|c|c|c|c|c|c|}
\hline \multirow[t]{2}{*}{ Description of inflow } & \multirow[t]{2}{*}{ Inflow } & \multicolumn{2}{|c|}{$\begin{array}{c}\text { Investment in } \\
\text { Tourism and } \\
\text { Transport }\end{array}$} & \multicolumn{2}{|c|}{$\begin{array}{l}\text { Investment in } \\
\text { market index }\end{array}$} \\
\hline & & $\begin{array}{l}\text { Index } \\
\text { return }\end{array}$ & Value & $\begin{array}{l}\text { Index } \\
\text { return }\end{array}$ & Value \\
\hline $\begin{array}{l}\text { 09/30/97 Liquid assets }(1,093) \text { minus debt }(852) \text { at the } \\
\text { end of fiscal year 1996/97 }\end{array}$ & 241.0 & & 241.0 & & 241.0 \\
\hline 01/12/98 Preussag sells steel business & 542.0 & $0.38 \%$ & 783.9 & $-2.73 \%$ & 776.4 \\
\hline $\begin{array}{l}04 / 20 / 98 \\
\text { (share 50\%) }\end{array}$ & 153.0 & $24.64 \%$ & $1,130.0$ & $30.34 \%$ & $1,165.0$ \\
\hline $\begin{array}{l}\text { 06/02/98 Preussag sells a company from its } \\
\text { components business }\end{array}$ & 0.0 & $2.60 \%$ & $1,159.5$ & $2.31 \%$ & $1,191.9$ \\
\hline 09/30/98 $\begin{array}{l}\text { Operating cash flow without tourism and } \\
\text { logistics }\end{array}$ & 116.9 & $-27.99 \%$ & 951.8 & $-19.06 \%$ & $1,081.7$ \\
\hline 10/20/98 Preussag sells its recycling unit & 0.0 & $3.76 \%$ & 987.6 & $1.84 \%$ & $1,101.6$ \\
\hline 11/11/98 $\begin{array}{l}\text { Preussag sells part of its plant construction } \\
\text { business }\end{array}$ & 0.0 & $2.38 \%$ & $1,011.1$ & $3.37 \%$ & $1,138.8$ \\
\hline 01/01/99 Preussag sells its coal mine & 82.0 & $7.56 \%$ & $1,169.6$ & $5.05 \%$ & $1,278.3$ \\
\hline $\begin{array}{l}\text { Preussag sells the mining and engineering } \\
\text { company Deilmann-Haniel (share: } 50.2 \% \text { ) }\end{array}$ & 29.0 & $0.35 \%$ & $1,202.7$ & $4.19 \%$ & $1,360.8$ \\
\hline $\begin{array}{l}\text { Preussag sells } 100 \% \text { of its plant construction } \\
\text { unit and } 50 \% \text { of the shipbuilding unit }\end{array}$ & 322.0 & $14.85 \%$ & $1,703.3$ & $-3.22 \%$ & $1,638.9$ \\
\hline 09/08/99 Preussag sells 4.6\% of Metaleurop S.A. & 10.0 & $1.23 \%$ & $1,734.3$ & $6.55 \%$ & $1,756.3$ \\
\hline $\begin{array}{c}\text { 09/30/99 Operating cash flow without tourism and } \\
\text { logistics }\end{array}$ & 233.5 & $-5.01 \%$ & $1,880.8$ & $-4.66 \%$ & 1,908.0 \\
\hline 03/27/00 Preussag sells 8.6\% of Metaleurop S.A. & 20.0 & $7.61 \%$ & $2,044.1$ & $49.36 \%$ & $2,869.8$ \\
\hline $\begin{array}{l}\text { 09/30/00 Operating cash flow without tourism and } \\
\text { logistics }\end{array}$ & 494.1 & $-5.67 \%$ & $2,422.3$ & $-14.55 \%$ & $2,946.4$ \\
\hline 10/05/00 Preussag sells part of its trading business & 58.0 & $1.11 \%$ & $2,507.3$ & $0.60 \%$ & $3,022.0$ \\
\hline $\begin{array}{l}\text { 12/31/00 Operating cash flow without tourism and } \\
\text { logistics }\end{array}$ & 139.4 & $-2.82 \%$ & $2,575.9$ & $-11.58 \%$ & $2,811.4$ \\
\hline $12 / 31 / 00$ Preussag sells 6800 apartments & 162.0 & $0.00 \%$ & $2,737.9$ & $0.00 \%$ & $2,973.4$ \\
\hline $\begin{array}{l}\text { 03/30/01 Preussag sells the fire protection firm } \\
\text { Minimax }\end{array}$ & 276.0 & $-4.65 \%$ & $2,886.5$ & $-7.16 \%$ & $3,036.6$ \\
\hline 03/30/01 Preussag sells 400 apartments & 10.0 & $0.00 \%$ & $2,896.5$ & $0.00 \%$ & $3,046.6$ \\
\hline $\begin{array}{c}04 / 26 / 01 \\
\text { Preussag sells the sanitary equipment } \\
\text { producer Kermi Group }\end{array}$ & 140.0 & $1.73 \%$ & $3,086.7$ & $4.28 \%$ & $3,317.0$ \\
\hline $\begin{array}{l}\text { 06/22/01 Preussag sells its construction materials unit } \\
\text { Fels Group }\end{array}$ & 750.0 & $1.75 \%$ & $3,890.6$ & $-1.72 \%$ & $4,010.1$ \\
\hline
\end{tabular}




\begin{tabular}{|c|c|c|c|c|c|}
\hline \multirow[t]{2}{*}{ Date } & \multirow[t]{2}{*}{ Inflow } & \multicolumn{2}{|c|}{$\begin{array}{c}\text { Investment in } \\
\text { Tourism and } \\
\text { Transport }\end{array}$} & \multicolumn{2}{|c|}{$\begin{array}{l}\text { Investment in } \\
\text { market index }\end{array}$} \\
\hline & & $\begin{array}{l}\text { Index } \\
\text { return }\end{array}$ & Value & $\begin{array}{l}\text { Index } \\
\text { return }\end{array}$ & Value \\
\hline $\begin{array}{l}\text { 07/06/01 Preussag sells most of its heating technology } \\
\text { business }\end{array}$ & 300.0 & $0.38 \%$ & $4,205.3$ & $-2.00 \%$ & $4,229.9$ \\
\hline $\begin{array}{c}\text { 07/16/01 } \begin{array}{l}\text { Preussag sells part of its oil and gas } \\
\text { exploration and its stake in Ruhrgas AG }\end{array} \\
\end{array}$ & 350.0 & $-1.07 \%$ & $4,510.4$ & $-0.28 \%$ & $4,568.1$ \\
\hline 08/23/01 Preussag sells the storage specialist KBB & 21.0 & $-2.90 \%$ & $4,400.6$ & $-8.24 \%$ & $4,212.7$ \\
\hline 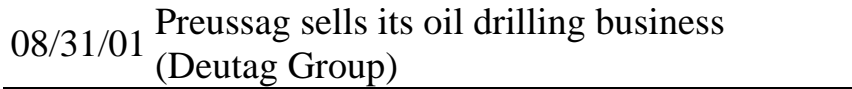 & 210.0 & $-1.11 \%$ & $4,562.0$ & $-1.32 \%$ & $4,367.2$ \\
\hline $\begin{array}{l}\text { 12/31/01 Operating cash flow without tourism and } \\
\text { logistics }\end{array}$ & 402.2 & $-6.94 \%$ & $4,647.5$ & $-0.30 \%$ & $4,756.5$ \\
\hline $\begin{array}{l}\text { Preussag sells the remaining } 50 \% \text { of its } \\
\text { shipbuilding unit (HDW AG) }\end{array}$ & 400.0 & $10.14 \%$ & $5,518.8$ & $3.61 \%$ & $5,328.1$ \\
\hline $\begin{array}{l}\text { 06/06/02 } \begin{array}{l}\text { Preussag sells part of its components } \\
\text { business }\end{array} \\
\text {. }\end{array}$ & 0.0 & $-5.28 \%$ & $5,227.6$ & $-10.07 \%$ & $4,791.4$ \\
\hline 07/01/02 Preussag sells its software subsidiary & 0.0 & $-3.40 \%$ & $5,049.8$ & $-5.16 \%$ & $4,544.4$ \\
\hline $\begin{array}{l}\text { 12/06/02 Preussag sells its electric-chemical business } \\
\text { (share: } 50 \% \text { ) }\end{array}$ & 0.0 & $-11.33 \%$ & $4,477.8$ & $-25.34 \%$ & $3,392.9$ \\
\hline 12/19/02 Preussag sells 14000 apartments & 260.0 & $-3.42 \%$ & $4,584.5$ & $-7.34 \%$ & $3,403.7$ \\
\hline 12/27/02 Preussag sells its domestic oil business & 1000.0 & $-2.39 \%$ & $5,474.8$ & $-3.70 \%$ & $4,277.7$ \\
\hline $\begin{array}{l}2 / 31 / 02 \\
\text { Operating cash flow without tourism and } \\
\text { logistics }\end{array}$ & 190.3 & $0.66 \%$ & $5,701.1$ & $1.76 \%$ & $4,543.2$ \\
\hline 01/22/03 Preussag sells its foreign oil business & 300.0 & $-5.13 \%$ & $5,708.8$ & $-2.58 \%$ & $4,726.0$ \\
\hline $\begin{array}{l}\text { 09/11/03 Preussag sells a large part of its trading } \\
\text { business }\end{array}$ & 200.0 & $28.76 \%$ & $7,550.9$ & $27.78 \%$ & $6,238.9$ \\
\hline 09/19/03 Preussag sells its 24\% stake in a power plant & 0.0 & $2.84 \%$ & $7,765.4$ & $0.52 \%$ & $6,271.3$ \\
\hline 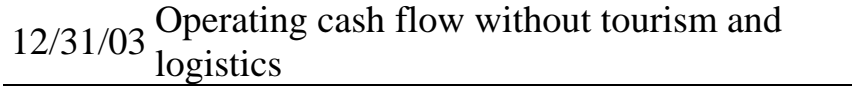 & 38.9 & $3.22 \%$ & $8,054.4$ & $9.95 \%$ & $6,934.0$ \\
\hline 03/31/04 Lehnkering AG (100\%) & 250.0 & $7.12 \%$ & $8,877.8$ & $-1.32 \%$ & $7,092.7$ \\
\hline 07/19/04 Algeco S.A. market capitalization (67\%) & 320.0 & $4.01 \%$ & $9,553.4$ & $-0.83 \%$ & $7,353.5$ \\
\hline $12 / 31 / 04 \begin{array}{l}\text { Operating cash flow without tourism and } \\
\text { logistics }\end{array}$ & 129.1 & $7.98 \%$ & $10,445.2$ & $10.84 \%$ & $8,279.6$ \\
\hline 12/31/04 VTG AG (100\%) & 400.0 & $0.00 \%$ & $10,845.2$ & $0.00 \%$ & $8,679.6$ \\
\hline 12/31/04 Metal trading unit (PNA Group) & 414.4 & $0.00 \%$ & $11,259.6$ & $0.00 \%$ & $9,094.0$ \\
\hline 12/31/04 Wolf GmbH (80\%) & 16.0 & $0.00 \%$ & $11,275.6$ & $0.00 \%$ & $9,110.0$ \\
\hline 12/31/04 Preussag Immobilien GmbH (100\%) & 96.4 & $0.00 \%$ & $11,372.1$ & $0.00 \%$ & $9,206.4$ \\
\hline
\end{tabular}




\section{Table 8: Management compensation at Preussag}

This table displays the average number of officers on Preussag's management board and their total and their average compensation for each fiscal year. In 2001, Preussag changed its end of fiscal year from September 30 to December 31. The table does not report the compensation for the shortened fiscal year that consisted only of the last quarter of 2000.

\begin{tabular}{cccc}
\hline \multirow{2}{*}{$\begin{array}{c}\text { Fiscal } \\
\text { year }\end{array}$} & $\begin{array}{c}\text { Average number } \\
\text { of officers }\end{array}$ & \multicolumn{2}{c}{ Compensation $(\boldsymbol{€}$ '000) } \\
\hline $1993 / 94$ & 8.25 & 4,337 & Average \\
\hline $1994 / 95$ & 8.00 & 5,157 & 526 \\
$1995 / 96$ & 8.00 & 5,227 & 645 \\
$1996 / 97$ & 8.00 & 5,024 & 653 \\
$1997 / 98$ & 6.50 & 5,232 & 805 \\
$1998 / 99$ & 4.00 & 5,163 & 1,291 \\
$1999 / 00$ & 4.00 & 6,323 & 1,581 \\
2001 & 6.00 & 8,165 & 1,361 \\
2002 & 6.00 & 10,222 & 1,704 \\
2003 & 5.17 & 9,342 & 1,808 \\
2004 & 4.00 & 7,969 & 1,992 \\
\hline
\end{tabular}

\section{Table 9: Voting rights at Preussag's AGM controlled by WestLB}

This table displays the percentage of Preussag's equity capital that was represented at Preussag's Annual General Meetings (AGM) from 1995 to 2004. It also shows the proportion of these voting rights that were controlled by WestLB alone or by WestLB and Niedersachsen Holding (NH). WestLB held a 33.3\% stake in Niedersachsen Holding (see Figure 1A). Niedersachsen Holding was dissolved by the end of 1998.

\begin{tabular}{lccr}
\hline & Capital & \multicolumn{2}{c}{ Voting rights at the AGM held by } \\
\cline { 3 - 4 } Date of AGM & $\begin{array}{c}\text { Cepresented at } \\
\text { AGM }\end{array}$ & WestLB & $\begin{array}{c}\text { WestLB } \\
\text { and NH }\end{array}$ \\
\hline 24. Mar. 1994 & N/A & N/A & N/A \\
30. Mar. 1995 & $70.3 \%$ & $41.4 \%$ & $56.2 \%$ \\
21. Mar. 1996 & $74.0 \%$ & $39.3 \%$ & $53.4 \%$ \\
26. Mar. 1997 & $66.5 \%$ & $43.8 \%$ & $59.4 \%$ \\
26. Mar. 1998 & $65.5 \%$ & $44.5 \%$ & $60.3 \%$ \\
31. Mar. 1999 & $67.0 \%$ & $49.3 \%$ & \\
12. Apr. 2000 & $39.0 \%$ & $84.6 \%$ & \\
18. May 2001 & $37.2 \%$ & $88.8 \%$ & \\
26. Jun. 2002 & $42.2 \%$ & $78.2 \%$ & \\
18. Jun. 2003 & $54.0 \%$ & $61.1 \%$ & \\
18. Mai. 2004 & $54.3 \%$ & $60.8 \%$ & \\
\hline Average: & $57.0 \%$ & $59.2 \%$ & \\
\hline
\end{tabular}




\section{Figure 1: Description of the WestLB/Preussag network}

The following figures show the cross-holdings and interlocking directorates in the WestLB/Preussag network at three points in time during the period 1994 to 2004. The percentages next to the arrows provide the voting rights of the firm at the start of the arrow in the firm at the tip of the arrow. The figures also list selected members of the executive and the supervisory boards. MM stands for 'member of the management board', CS for 'chairman of the supervisory board', and MS for 'member of the supervisory board.'

Figure 1A: January 1994 until June 1997

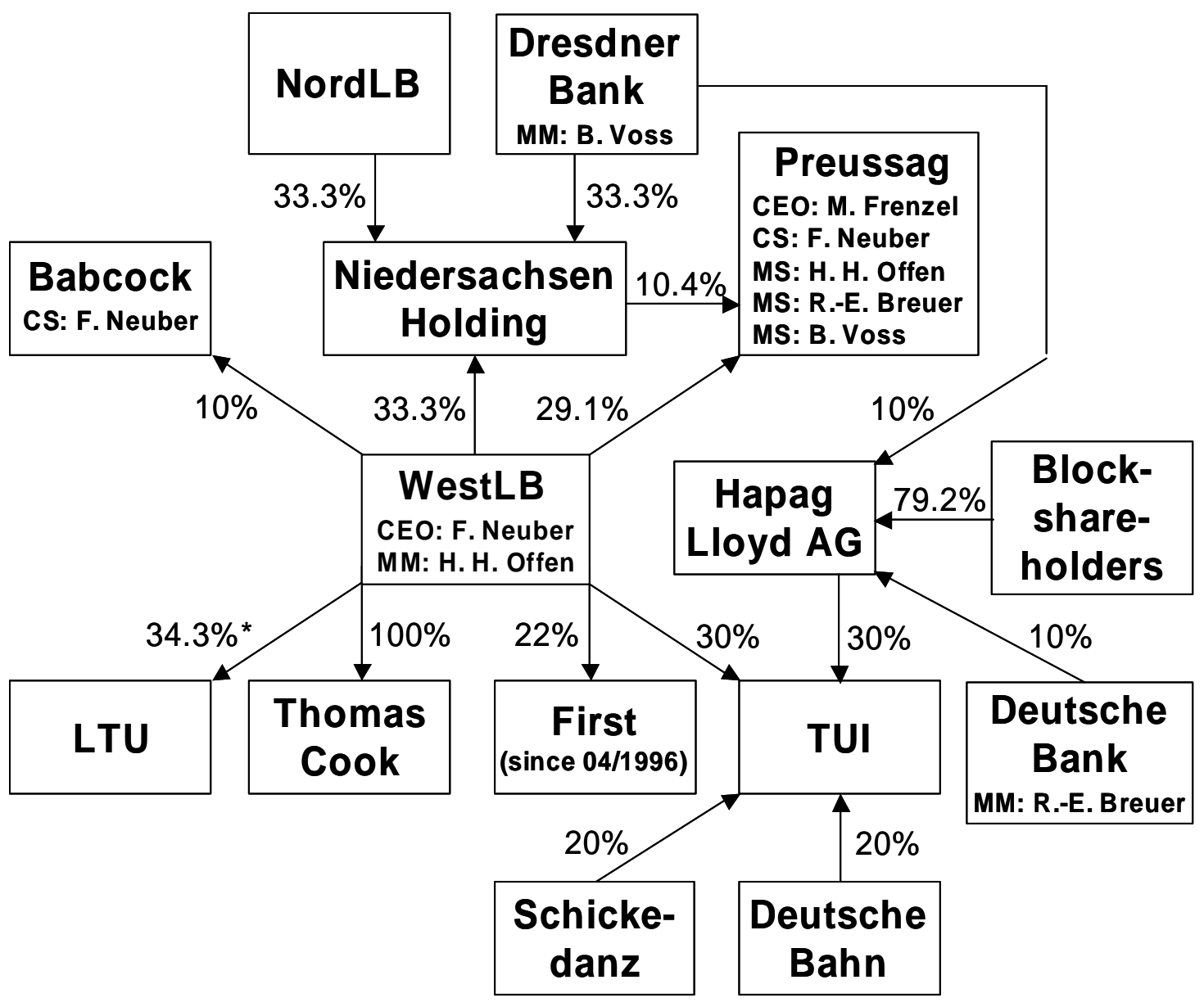

* According to Handelsblatt from June 5, 1992, WestLB holds 34.3\% of LTU's cash-flow rights but has the majority of the voting rights. 
Figure 1B: December 1999

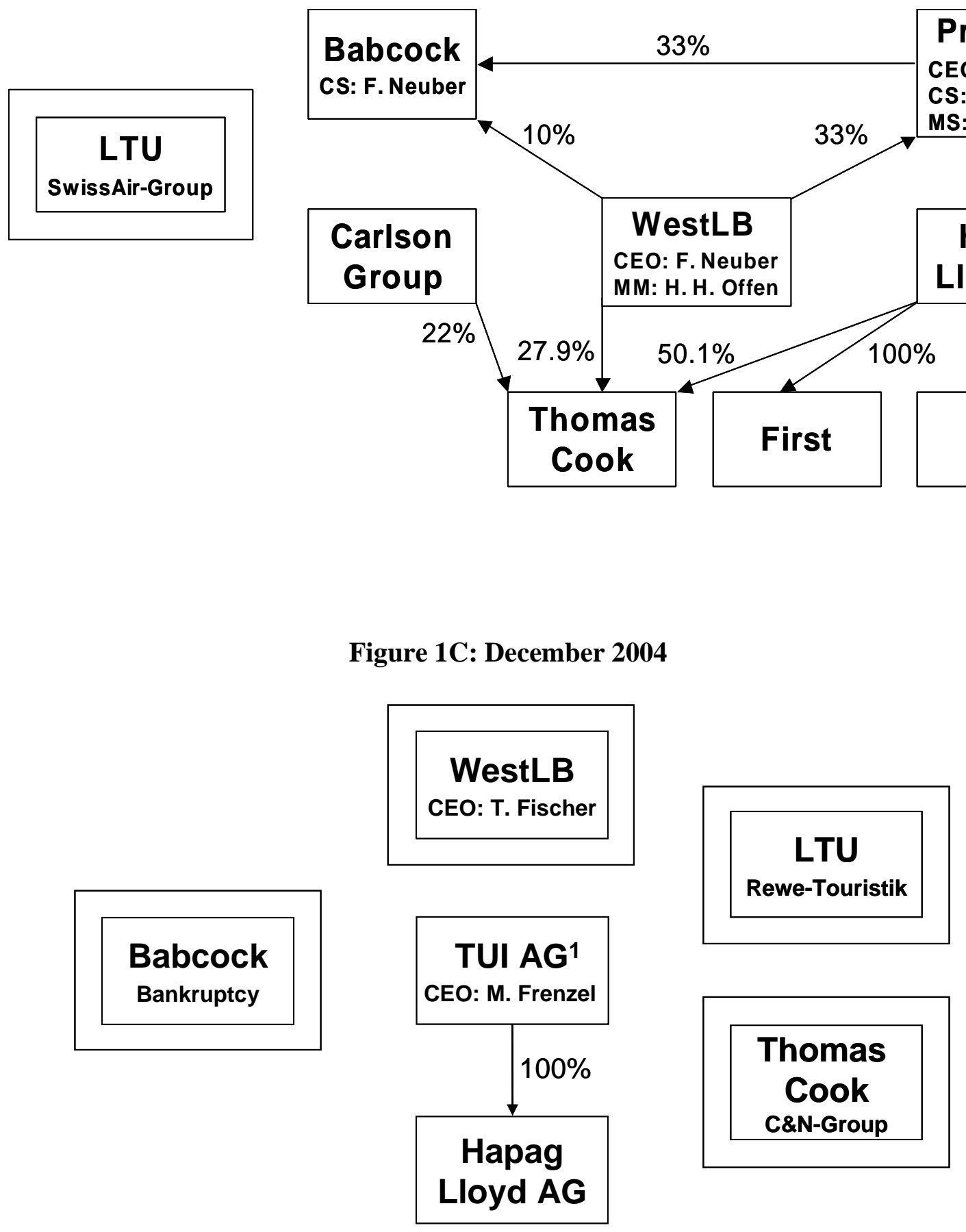




\section{Figure 2: Preussag's stock price history}

The three figures show Preussag's performance index ('Preussag') and the German stock market's performance index ('CDAX') over the decade from January 1994 to December 2004. Both series are normalized to 100 on January 1, 1994, June 11, 1997, and September 11, 2001.

Figure 2A: Preussag’s stock price from January 1, 1994 to June 10, 1997

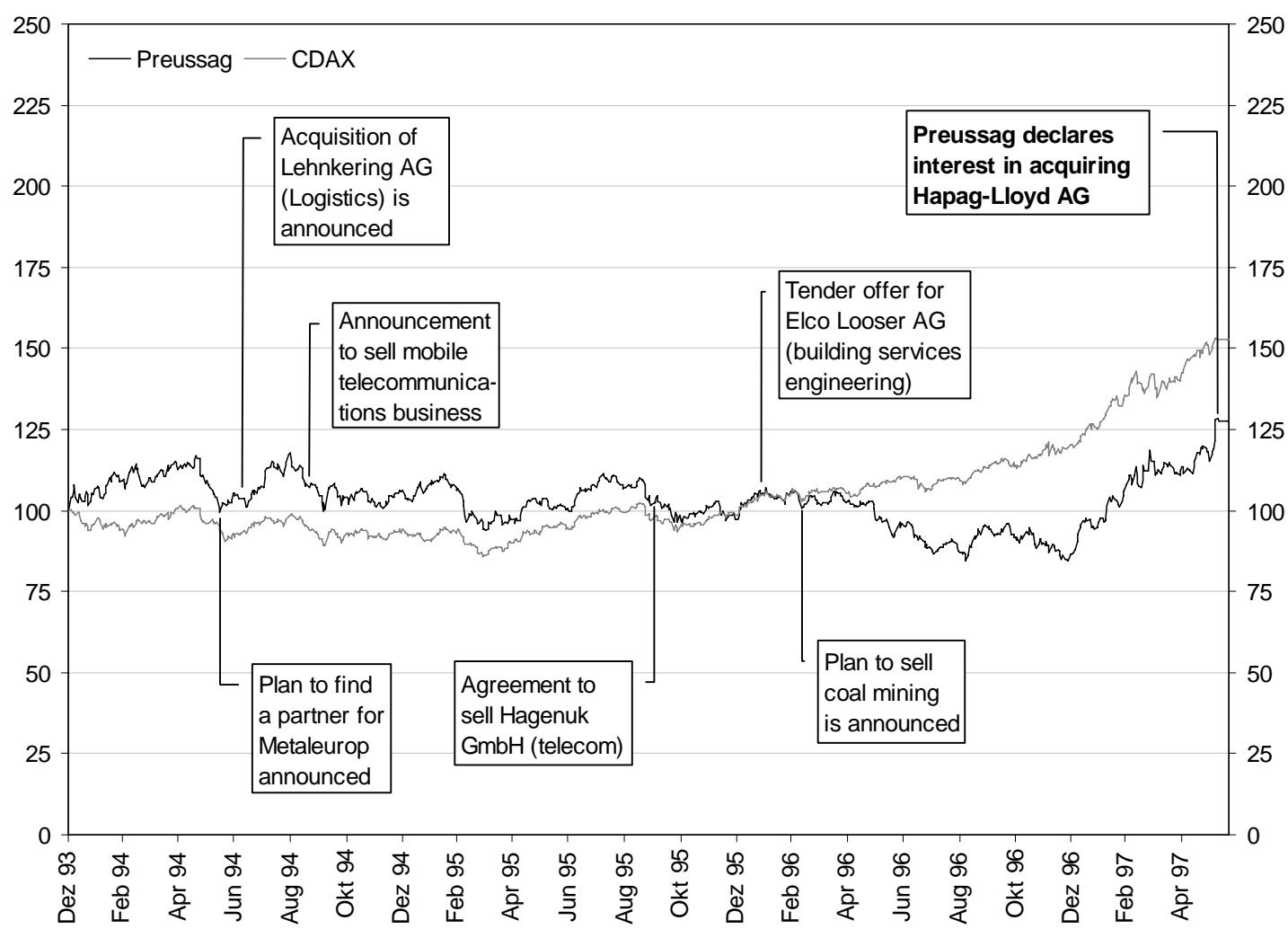


Figure 2B: Preussag's stock price from June 11, 1997 to September 10, 2001

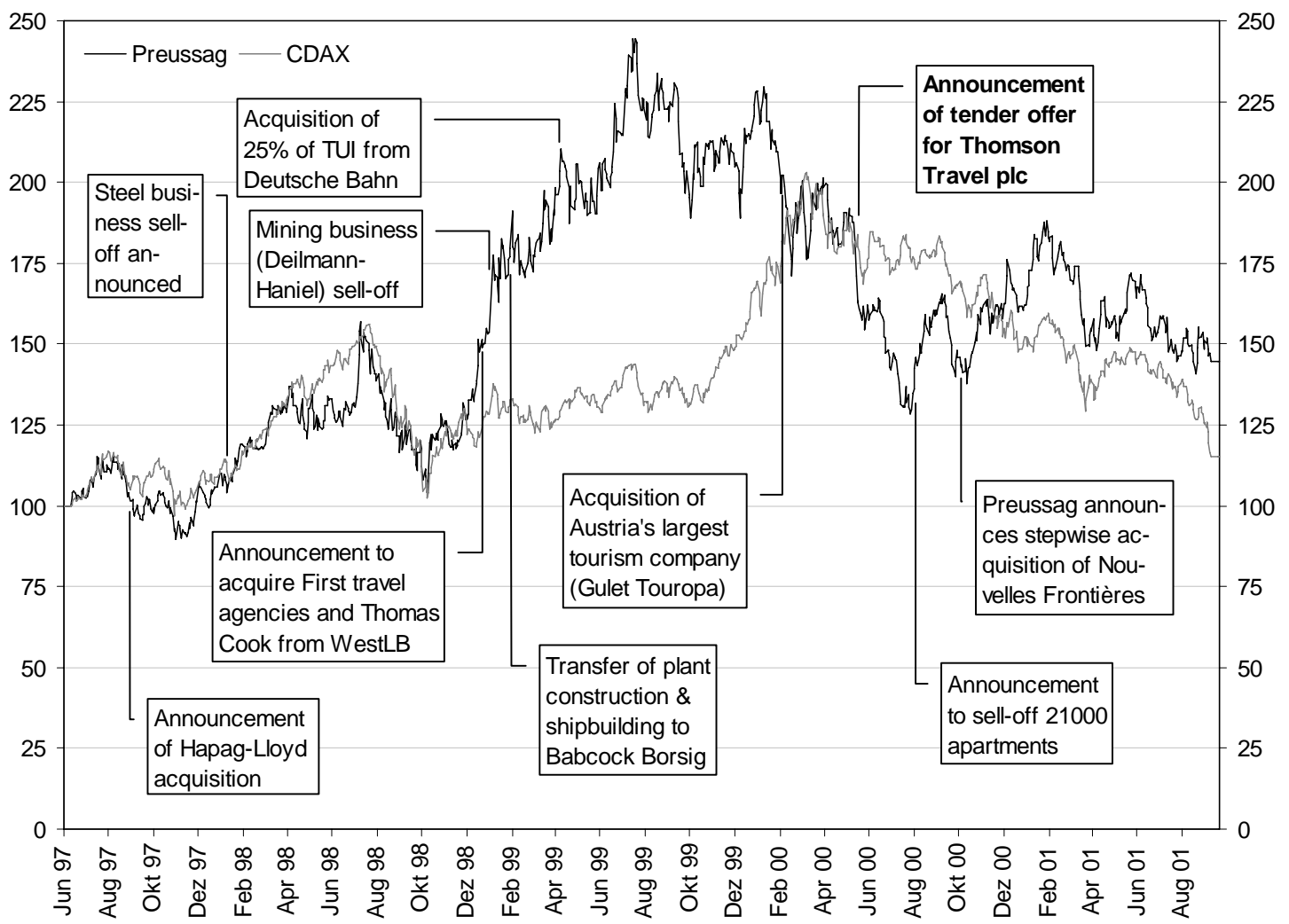

Figure 2C: Preussag's stock price from September 11, 2001 to December 31, 2004

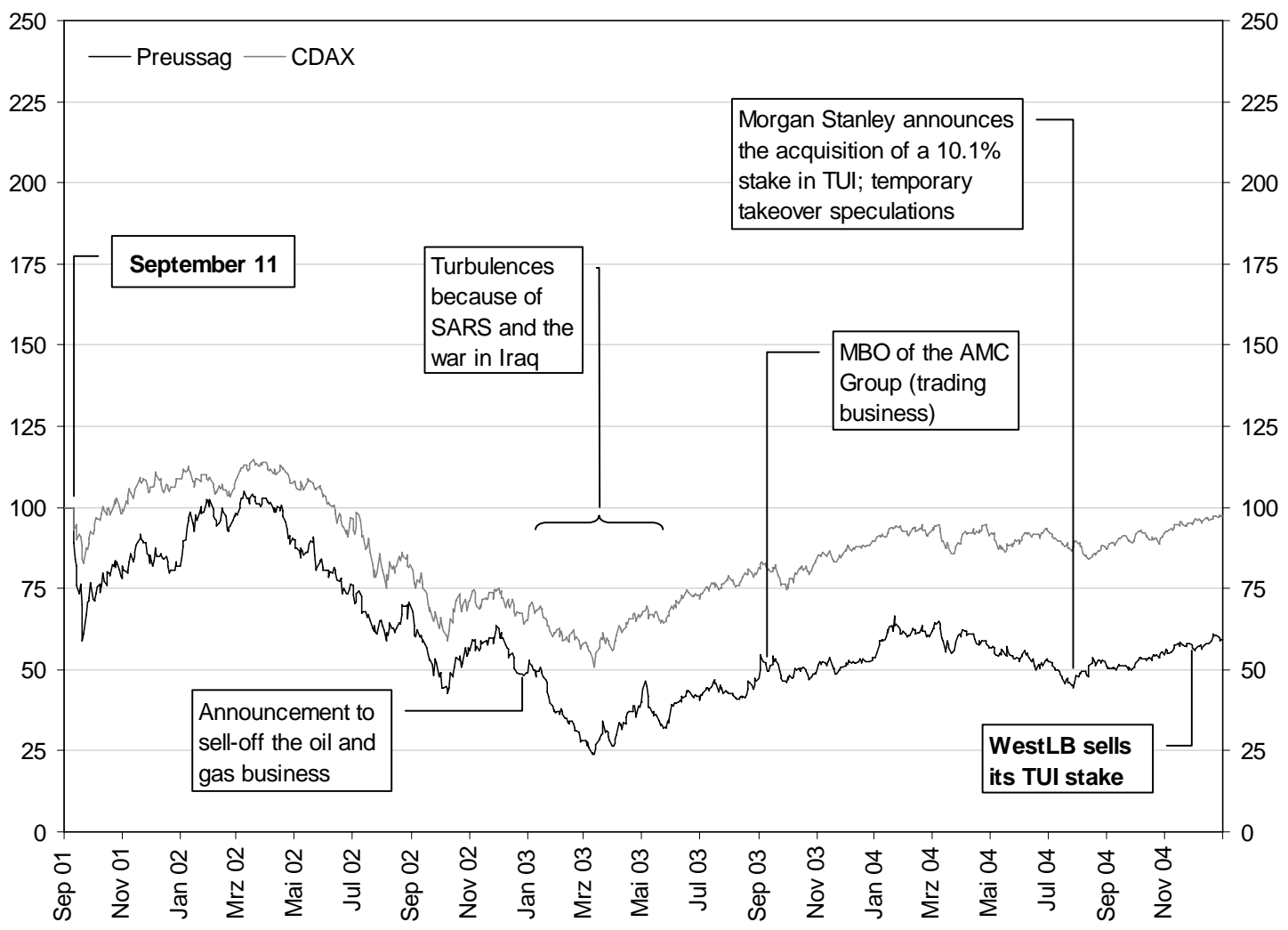




\section{Figure 3: Correlations of Preussag's stock with the market and with industry portfolios}

Figure 3a shows the regression coefficient of a regression of Preussag's daily stock returns on the daily CDAX returns and an intercept over a 500 trading day moving window ( -250 to +250 days). The intercept is not displayed in the figures. Figure $3 b$ shows the results of a similar regression on the returns of the tourism and transport index and the steel and engineering index.

\section{Figure 3A: Regression coefficient of Preussag's returns on the market return}

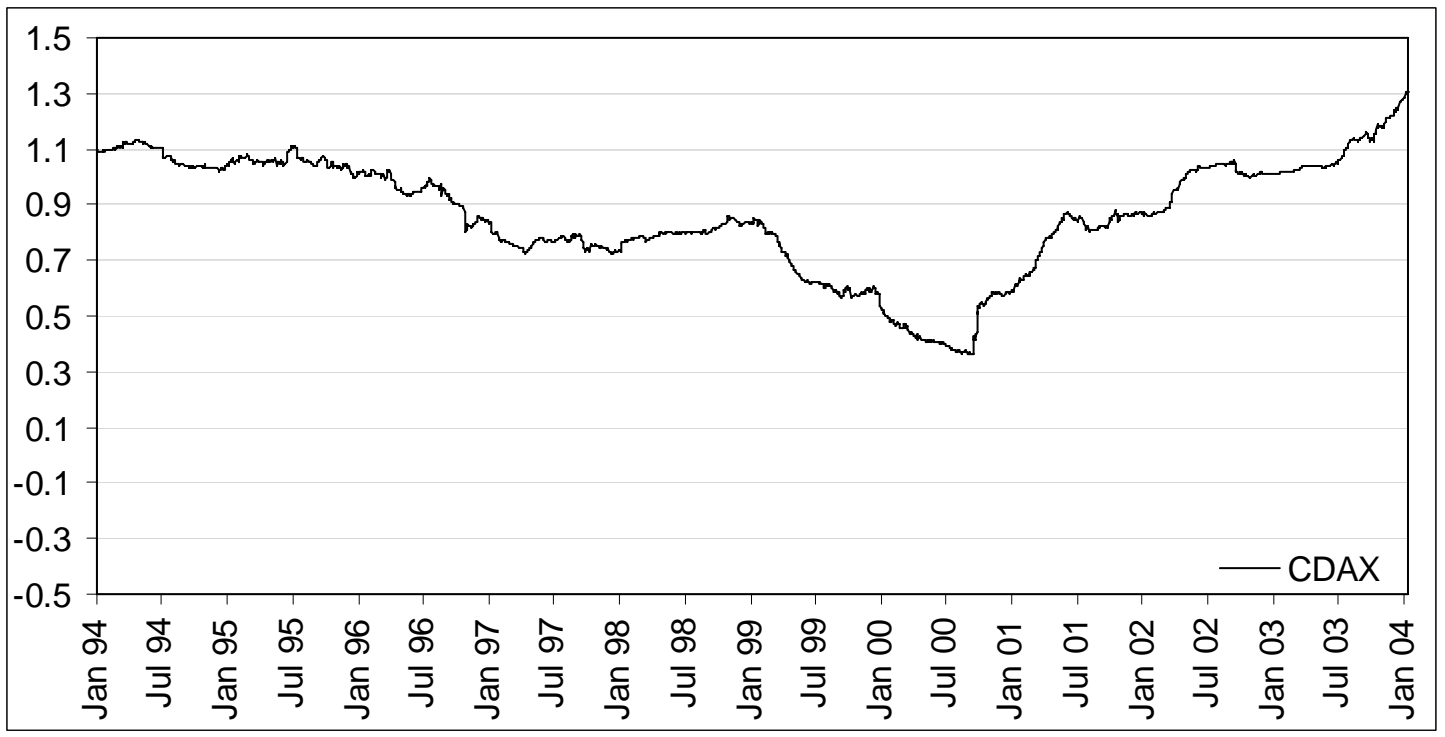

Figure 3B: Regression coefficients of Preussag's returns on the returns of two industry portfolios

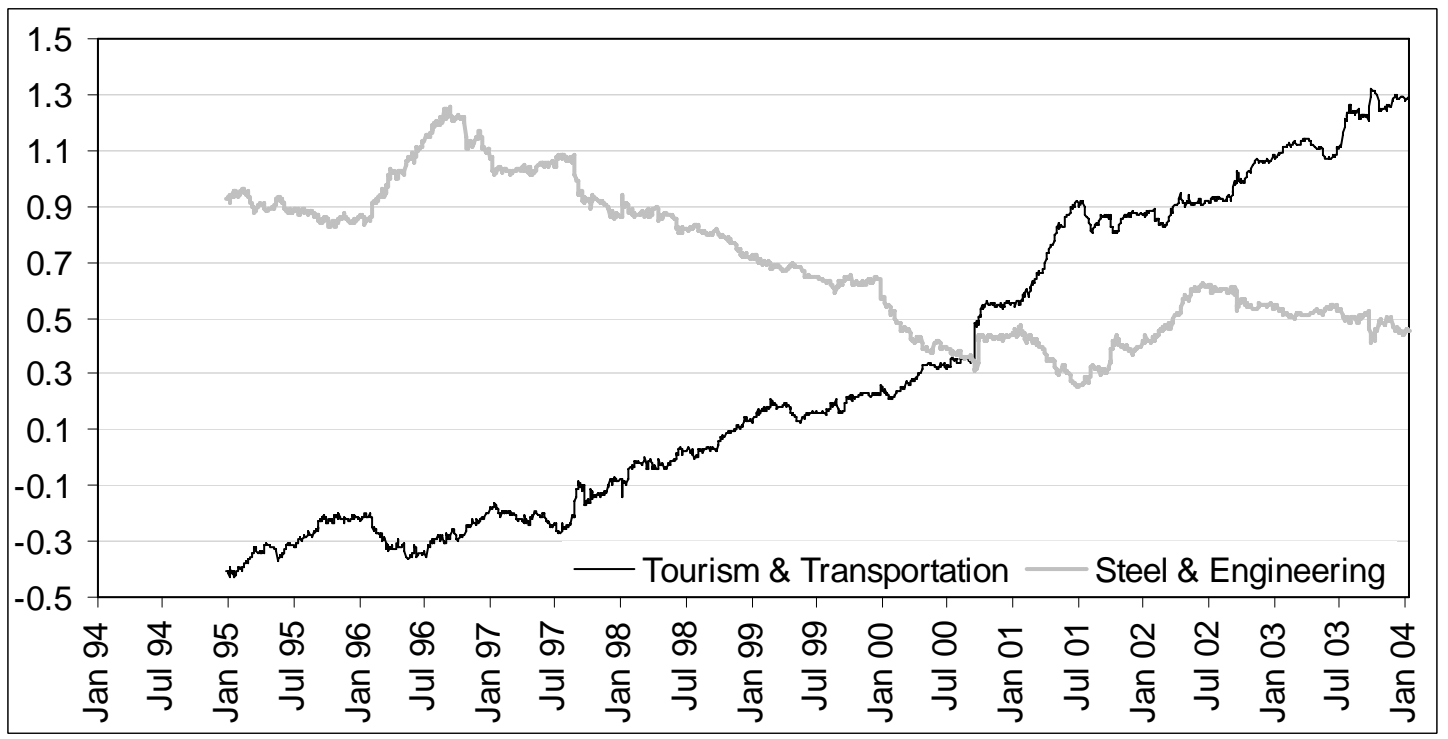




\section{Figure 4: Preussag's supervisory board and board overlaps}

This figures displays the firms, organizations and individuals that were represented in Preussag's supervisory board between 1994 and 2004. Three of these firms had themselves a WestLB representative on their supervisory board. Details on the individual interlocks are provided in the footnotes. MM stands for 'member of the management board', CS for 'chairman of the supervisory board', and MS for 'member of the supervisory board.'

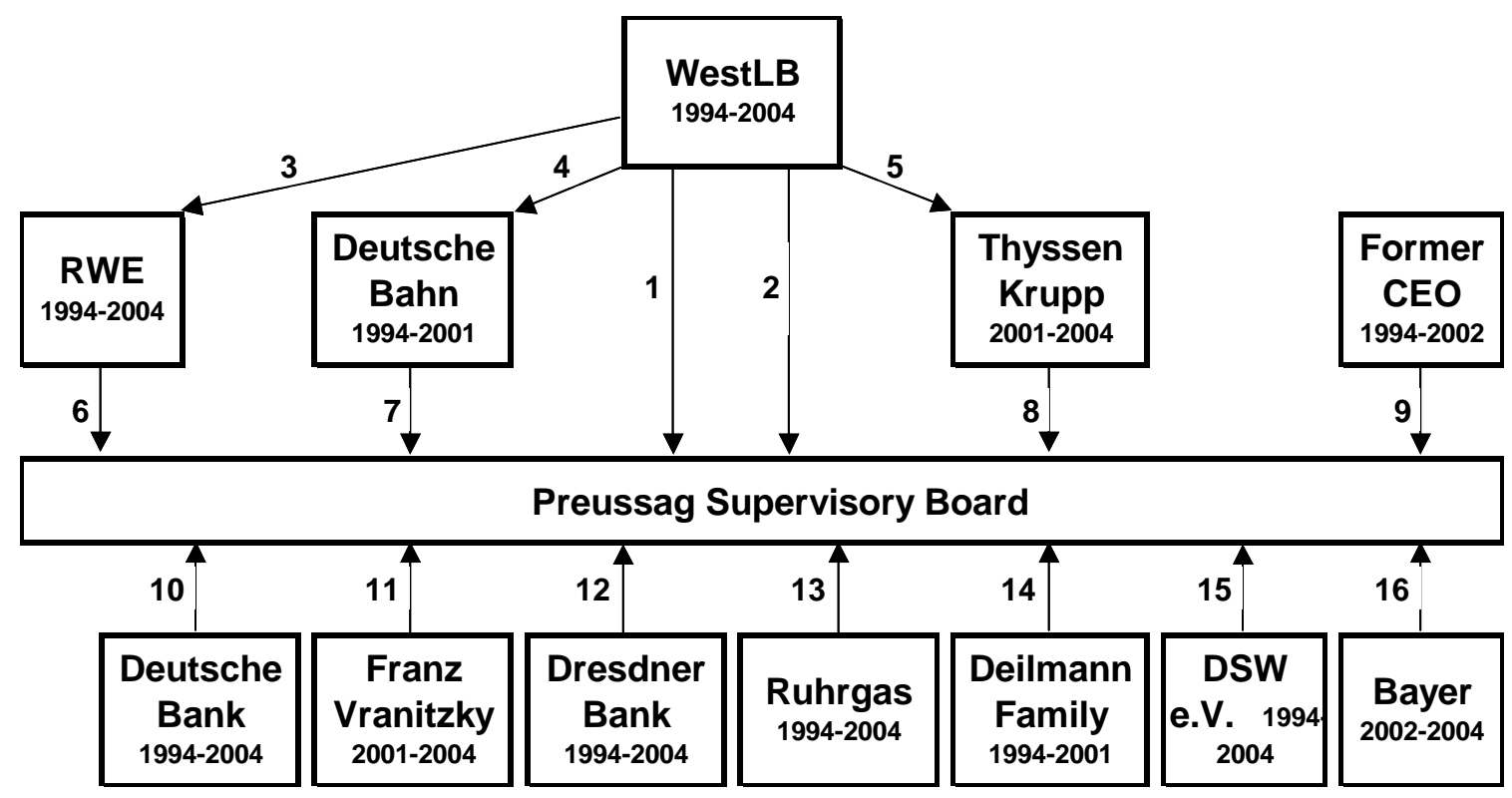

(1) Friedel Neuber: CEO of WestLB (until 2001), CS of Preussag (died 10/23/2004), followed by Norbert Emmerich (11/5/2004 - 1/26/2005); new chairman Jürgen Krumnow (since 11/10/2004).

(2) Hans Henning Offen: MM of WestLB (until 2002); Since Mr. Offen left Preussag's supervisory board (6/18/2003), WestLB was represented by Jürgen Sengera (6/18/2003 - 8/21/2003), followed by Johannes Ringel (9/8/2003 - 1/12/2004) and Thomas Fischer (CEO) (1/16/2004 - 1/26/2005).

(3) Friedel Neuber: Chairman of RWE's supervisory board (died 10/23/2004), followed by Thomas Fischer; H.-H.Offen: Supervisory board memberships of a subsidiary of RWE.

(4) Friedel Neuber: Member of Deutsche Bahn's supervisory board (died 10/23/2004).

(5) Friedel Neuber: Chairman of ThyssenKrupp's supervisory board (died 10/23/2004); H.-H.Offen: Supervisory board memberships of a subsidiary of ThyssenKrupp.

(6) Herbert Krämer: MM of RWE and MS of Preussag (until 1996). Dietmar Kuhnt: CEO of RWE and MS of Preussag (1996-2003).

(7) Heinz Dürr: CEO of Deutsche Bahn (until 1997) and CS of Deutsche Bahn (1997-1999).

(8) Ekkehard Schulz: CEO of ThyssenKrupp.

(9) Günther Saßmannshausen: Former CEO of Preussag (until 1988).

(10) Rolf-E. Breuer: CEO of Deutsche Bank and MS of Preussag (until 1997). Jürgen Krumnow: MM of Deutsche Bank (until 1999), Advisor of Deutsche Bank (since 2000) and MS of Preussag (since 1997). Deutsche Bank sold their 10\% stake in Hapag-Lloyd to Preussag in 1997.

(11) Franz Vranitzky: Former Austrian Chancellor and member of the Austrian Social Democratic Party.

(12) Bernd W. Voss: MM (until 2001) and MS (since 2002) of Dresdner Bank. Dresdner Bank sold their 10\% stake in Hapag-Lloyd to Preussag in 1997.

(13) Klaus Liesen: CEO of Ruhrgas (until 1996) and CS of Ruhrgas (since 1996).

(14) Hans Carl Deilmann: Owner and CEO of C.Deilmann AG, a company taken over by Preussag in several steps during the 1980s and early 1990s, MS of Preussag (until 1996). Jürgen Deilmann: CEO of Deilmann-Montan GmbH and MS Preussag (1997-2001).

(15) Gerold Bezzenberger: MM of DSW, a German investor protection association, and MS of Preussag (until 2001). Jella S. Benner-Heinacher: CEO of DSW and MS of Preussag (2001-2004).

(16) Manfred Schneider: CS of Bayer. 